\title{
Dynamics of dissolved inorganic carbon and aquatic metabolism in the Tana River basin, Kenya
}

\author{
F. Tamooh ${ }^{1,2}$, A. V. Borges ${ }^{3}$, F. J. R. Meysman ${ }^{4,5}$, K. Van Den Meersche ${ }^{4, *}$, F. Dehairs ${ }^{4}$, R. Merckx ${ }^{1}$, and S. Bouillon ${ }^{1}$ \\ ${ }^{1}$ Katholieke Universiteit Leuven, Department of Earth and Environmental Sciences, Celestijnenlaan 200E, 3001 Leuven, \\ Belgium \\ ${ }^{2}$ 2Kenya Wildlife Service, P.O. Box 82144-80100, Mombasa, Kenya \\ ${ }^{3}$ Université de Liège, Unité d'Océanographie Chimique, Allée du 6 Août, 17, 4000, Belgium \\ ${ }^{4}$ Vrije Universiteit Brussel, Department of Analytical and Environmental Chemistry, Pleinlaan 2, 1050 Brussel, Belgium \\ ${ }^{5}$ Royal Netherlands Institute of Sea Research, Korringaweg 7, 4401 NT Yerseke, the Netherlands \\ * current address: French Agricultural Research Centre for International Development, UMR Eco \& Sols, SUP AGRO Bât. 12, \\ 2 Place Viala, 34060 Montpellier Cedex 2, France
}

Correspondence to: F. Tamooh (fredrick.tamooh@ees.kuleuven.be)

Received: 28 February 2013 - Published in Biogeosciences Discuss.: 14 March 2013

Revised: 21 September 2013 - Accepted: 27 September 2013 - Published: 4 November 2013

\begin{abstract}
A basin-wide study was conducted in the Tana River basin (Kenya) in February 2008 (dry season), September-November 2009 (wet season) and JuneJuly 2010 (end of the wet season) to assess the dynamics and sources of dissolved inorganic carbon (DIC) as well as to quantify $\mathrm{CO}_{2}$ fluxes, community respiration $(R)$, and primary production $(P)$. Samples were collected along the altitudinal gradient (from 3600 to $8 \mathrm{~m}$ ) in several headwater streams, reservoirs (Kamburu and Masinga), and the Tana River mainstream. DIC concentrations ranged from 0.2 to $4.8 \mathrm{mmol} \mathrm{L}^{-1}$, with exceptionally high values $\left(3.5 \pm 1.6 \mathrm{mmol} \mathrm{L}^{-1}\right)$ in Nyambene Hills tributaries. The wide range of $\delta^{13} \mathrm{C}_{\mathrm{DIC}}$ values $(-15.0$ to $-2.4 \%$ ) indicate variable sources of DIC, with headwater streams recording more positive signatures compared to the Tana River mainstream. With with only a few exceptions, the entire riverine network was supersaturated in $\mathrm{CO}_{2}$, implying the system is a net source of $\mathrm{CO}_{2}$ to the atmosphere. $p \mathrm{CO}_{2}$ values were generally higher in the lower Tana River mainstream compared to headwater tributaries, opposite to the pattern typically observed in other river networks. This was attributed to high suspended sediment in the Tana River mainstream fuelling in-stream community respiration and net heterotrophy. This was particularly evident during the 2009 wet season campaign (median $p \mathrm{CO}_{2}$ of $1432 \mathrm{ppm}$ ) compared to the 2010 end of the wet season (1002 ppm) and 2008 dry season
\end{abstract}

(579 ppm). First-order estimates show that in-stream community respiration was responsible for the bulk of total $\mathrm{CO}_{2}$ evasion ( 77 to $114 \%$ ) in the Tana River mainstream, while in the tributaries, this could only account for 5 to $68 \%$ of total $\mathrm{CO}_{2}$ evasion. This suggests that $\mathrm{CO}_{2}$ evasion in the tributaries was to a substantial degree sustained by benthic mineralisation and/or lateral inputs of $\mathrm{CO}_{2}$-oversaturated groundwater. While sediment loads increased downstream and thus light availability decreased in the water column, both chlorophyll $a\left(0.2\right.$ to $\left.9.6 \mu \mathrm{g} \mathrm{L}^{-1}\right)$ and primary production $(0.004$ to $7.38 \mu \mathrm{mol} \mathrm{C} \mathrm{L} \mathrm{C}^{-1} \mathrm{~h}^{-1}$ ) increased consistently downstream. Diurnal fluctuations of biogeochemical processes were examined at three different sites along the river continuum (headwater, reservoir and mainstream), and were found to be substantial only in the headwater stream, moderate in the reservoir and not detectable in the Tana River mainstream. The pronounced diurnal fluctuations observed in the headwater stream were largely regulated by periphyton as deduced from the low chlorophyll $a$ in the water column.

\section{Introduction}

Rivers are becoming increasingly more recognised as important not only in the transport of carbon (C) between the terrestrial and marine environments but also in terms of $\mathrm{C}$ 
storage and processing. River systems are typically a source of $\mathrm{CO}_{2}$ to the atmosphere, partly due to receiving $\mathrm{CO}_{2}$-rich groundwater and partly due to heterotrophic processes within the system. Thus, dissolved inorganic carbon (DIC, comprising $\mathrm{HCO}_{3}^{-}, \mathrm{CO}_{3}^{2-}$ and $\mathrm{CO}_{2}$ ) is an important component in river biogeochemistry. The dynamics of riverine DIC are primarily controlled by watershed inputs and in-stream processes, which lead to either addition or removal of carbon from the DIC pool and which also change the $\delta^{13} \mathrm{C}_{\mathrm{DIC}}$ values of riverine water (Fig. 1). The input of terrestrial organic matter (and the relative contribution of $\mathrm{C} 3$ over $\mathrm{C} 4$ plants to this), the weathering of carbonate/silicate minerals within the bedrock and the ratio of groundwater discharge to surface runoff are the main watershed processes controlling the dynamics of riverine DIC and its $\delta^{13} \mathrm{C}$ signature. Additional in-stream processes impacting DIC dynamics include $\mathrm{CO}_{2}$ exchange with the atmosphere, in-stream dissolution or precipitation of carbonate/silicate minerals, primary production $(P)$ and community respiration $(R)$ (McConnaughey et al., 1994; Amiotte-Suchet et al., 1999; Abril et al., 2003; Finlay and Kendall, 2007). The strength of each of these processes depends on the size of the river and its productivity (Finlay, 2003) as well as the geology and hydrology of the basin (Bullen and Kendall, 1998), and varies seasonally as a function of temperature and discharge. The complexity of all these processes and their interplay makes it difficult to constrain the sources of riverine DIC.

Riverine carbon undergoes a high degree of transformation and some degree of retention as it cycles from the terrestrial biosphere to the ocean (Cole et al., 2007; Aufdenkampe et al., 2011). In most cases, this results in supersaturation of $\mathrm{CO}_{2}$ in fluvial systems and significant $\mathrm{CO}_{2}$ evasion to the atmosphere (Kempe 1984; Telmer and Veizer, 1999; Cole and Caraco, 2001; Richey et al. 2002; Cole et al., 2007; Aufdenkampe et al., 2011). Quantitative assessment of riverine $\mathrm{CO}_{2}$ degassing in tropical rivers is critical in the context of carbon cycling, particularly considering that tropical systems account for $\sim 70 \%$ of global riverine carbon fluxes, partly owing to their large areal extent, varying climatic conditions and diverse land-use covers (Milliman and Farnsworth, 2011).

In recent papers (Aufdenkampe et al., 2011; Butman and Raymond, 2011), the global freshwater systems $\mathrm{CO}_{2}$ evasion to the atmosphere has been estimated to be of the order of $\sim 3.3 \mathrm{Pg} \mathrm{C} \mathrm{yr}^{-1}$, three-fold greater than total carbon transport $\left(\sim 0.9 \mathrm{PgC} \mathrm{yr}^{-1}\right)$ to the global ocean. Such high $\mathrm{CO}_{2}$ evasion necessitates improved understanding of DIC dynamics in both local and regional systems as well as underlying drivers of carbon cycling. The above $\mathrm{CO}_{2}$ evasion estimate is prone to large uncertainty, and a range of estimates has been proposed, with Cole et al. (2007) giving a much more conservative number of $0.75 \mathrm{Pg} \mathrm{C} \mathrm{yr}^{-1}$. This is partly due to the lack of sufficient data to provide a representative and correct scaled flux, particularly in tropical systems (Regnier et al., 2013).

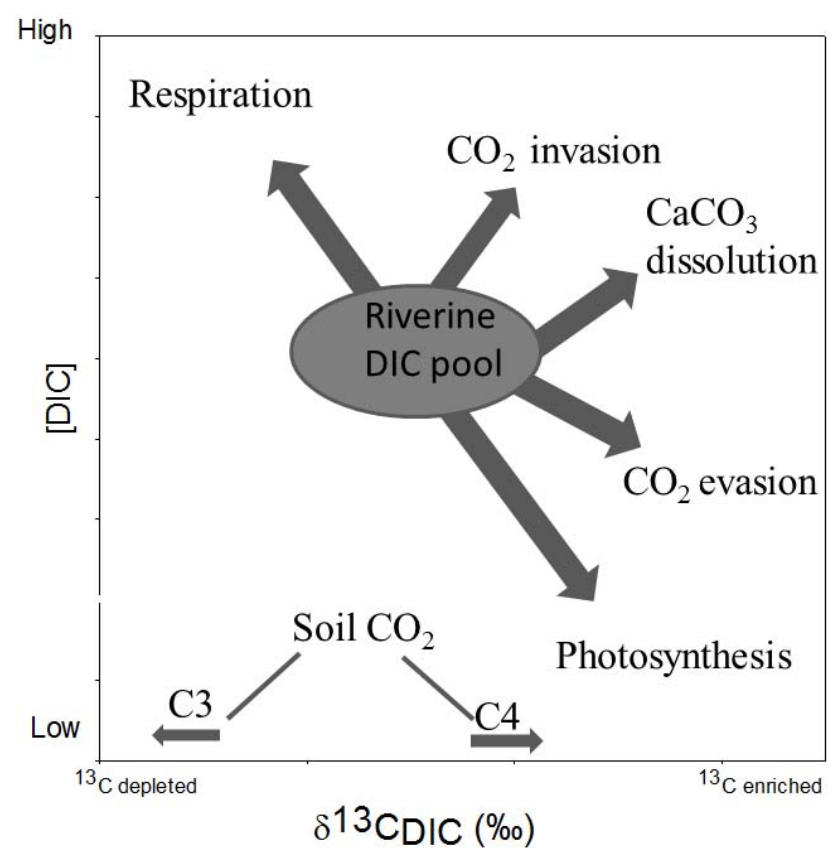

Fig. 1. Conceptual model showing the main watershed and instream biogeochemical processes controlling riverine DIC concentration and $\delta^{13} \mathrm{C}_{\mathrm{DIC}}$ signatures.

In recent years, the application of isotopic proxies has become invaluable in understanding riverine carbon cycling. Based on the premise that various carbon sources have distinct $\delta^{13} \mathrm{C}$ values, $\delta^{13} \mathrm{C}_{\text {DIC }}$ signatures have been used in a wide range of fluvial systems to constrain the biological and geological sources of DIC (Amiotte-Suchet et al., 1999; Finlay, 2003; Doctor et al., 2008; Brunet et al., 2005, 2009). For instance, riverine DIC predominantly derived from oxidation of organic matter will have $\delta^{13} \mathrm{C}$ values of about -28 and $-13 \%$ for by $\mathrm{C} 3$ and $\mathrm{C} 4$ plants respectively, or $-8 \%$ if derived from atmospheric air exchange. On the other hand, $\mathrm{CaCO}_{3}$ dissolution will shift $\delta^{13} \mathrm{C}$ signatures to heavier values $\left(\delta^{13} \mathrm{C}\right.$ value of carbonate is close to $0 \%$ if from marine origin) (Finlay, 2003; Brunet et al., 2005, 2009).

In order to quantify the predominant riverine metabolic activity, application of both the $\delta^{18} \mathrm{O}_{\mathrm{DO}}$ technique $(\mathrm{DO}=$ dissolved oxygen $)$ and light and dark bottle incubation experiments have effectively been employed in past studies (Sinada and Karim, 1984; Cole and Caraco, 2006; Gazeau et al., 2007). The global average $\delta^{18} \mathrm{O}$ of atmospheric oxygen is $+23.5 \%$, but fractionation during gas exchange across the air-water interface results in DO that is $\sim 0.7 \%$ heavier than atmospheric oxygen, and thus DO in isotopic equilibrium with air will have $\delta^{18} \mathrm{O}$ of $+24.2 \%$ o (Nimick et al., 2011). Aquatic photosynthesis lowers the isotopic composition of source water since it produces DO that is similar in isotopic composition to source water, while aquatic respiration causes a kinetic isotopic fractionation of molecular oxygen, and hence enriching water with heavier 
isotope (Parker et al., 2005). $\delta^{18} \mathrm{O}_{\mathrm{DO}}$ can be used to quantify the rates of photosynthesis and respiration in aquatic systems. In addition, monitoring of diurnal fluctuations in riverine biogeochemical proxies can equally provide quantitative information on river metabolism (Odum, 1956; Staehr et al., 2010).

According to the river continuum concept (RCC; Vannote et al., 1980), rivers show a predictable downstream variation in the linkage with the terrestrial environment. Thus, forested headwater streams (1st-3rd order) would be predominantly heterotrophic since metabolism is fuelled by allochthonous subsidies, whereas mid-order (4th-6th) streams would be predominantly autotrophic without significant riparian canopy cover. Large rivers ( $>7$ th order) revert to heterotrophy since $P$ would be limited by increased turbidity and depth; thus $R$ exceeds $P$. Riverine $P$ and $R$ rates are rarely quantitatively assessed at basin-wide scale despite their significance in understanding the functioning of riverine systems, yet it can be safely stated that most large rivers do not conform with the original tenets of the RCC due to altered lateral exchange with floodplains and flow discontinuities (Maiolini and Bruno, 2007). Since the RCC, a variety of alternative concepts to describe matter and energy flow have been developed, as reviewed by Bouwman et al. (2013). The metabolic balance between riverine $P$ and $R$ defines whether an ecosystem is net heterotrophic $(P: R<1)$ or net autotrophic $(P: R>1)$ (Odum 1956; Venkiteswaran et al., 2007). Most heterotrophic freshwater aquatic systems are sustained by subsidies of organic materials input from terrestrial biome (Cole and Caraco, 2001), which decompose within the riverine system, and as such influence carbon concentrations and their isotopic composition. The predominant metabolic activity thus depends on the magnitude of allochthonous inputs and the subsequent fraction respired versus autochthonous production (Cole and Caraco, 2001).

With this background, the present study examines the riverine DIC dynamics and $\delta^{13} \mathrm{C}_{\text {DIC }}$ values in the Tana River basin (Kenya), based on three basin-wide sampling campaigns covering the dry season, wet season and end of the wet season in order to constrain main sources of DIC. To quantify the strength of the riverine $\mathrm{CO}_{2}$ sources, we estimated both $p \mathrm{CO}_{2}$ and $\mathrm{CO}_{2}$ fluxes in an attempt to identify the primary $\mathrm{CO}_{2}$ evasion hotspots within the Tana River basin. In addition, the study also examines the longitudinal changes in the magnitude of riverine $P$ and $R$ rates. We further examined to what extent pelagic respiration sustained the $\mathrm{CO}_{2}$ evasion. Finally, we monitored biogeochemical parameters during diurnal cycles at three different sites along the river continuum representing headwater streams, reservoirs and the Tana River mainstream.

\section{Materials and methods}

\subsection{Study area}

The Tana River is the longest river in Kenya $(\sim 1100 \mathrm{~km})$, with a total catchment area of $\sim 96000 \mathrm{~km}^{2}$ (Fig. 2a). The river system can be separated into two main parts, here referred to as "Tana headwaters" and the "lower Tana mainstream". The Tana headwaters consists of numerous tributaries, which originate from the Aberdare Range in the central highlands of Kenya, the highlands around Mt Kenya, and the Nyambene Hills in eastern Kenya (Fig. 2a). The lower Tana mainstream encompasses the section downstream of the Nyambene Hills, where the river flows southeast for about $700 \mathrm{~km}$ through semiarid plains. Along this stretch, tributaries only discharge in short pulses during the wet season. As a result, the lower Tana mainstream forms a single transport channel during the dry season, delivering material to the Indian Ocean (Maingi and Marsh, 2002). The lower Tana River has extensive floodplains between the towns of Garissa and Garsen, but floodplain inundation has been irregular in recent decades due to the river flow regulation by five hydroelectric dams upstream (Maingi and Marsh, 2002). The associated reservoirs have a combined surface area of $\sim 150 \mathrm{~km}^{2}$, and a significant amount of sediment is trapped by these dams (Dunne and Ongweny, 1976; Brown and Schneider, 1998). Masinga is the largest reservoir (commissioned in 1981), and has a surface area of $\sim 120 \mathrm{~km}^{2}$ and a storage capacity of $\sim 1560 \times 10^{6} \mathrm{~m}^{3}$, while the Kamburu Reservoir (the third largest, commissioned in 1974) has a surface area of $\sim 15 \mathrm{~km}^{2}$ and a storage capacity of $\sim 123 \times 10^{6} \mathrm{~m}^{3}$ (GOK, TARDA, 1982). The Tana River basin includes different ecological zones experiencing different rainfall patterns, decreasing from the headwaters (altitude $>3050 \mathrm{~m}$, annual precipitation $\sim 1800 \mathrm{~mm} \mathrm{yr}^{-1}$ ), upper highlands (altitude $2450-3050 \mathrm{~m}$, annual precipitation $\sim 2200 \mathrm{~mm} \mathrm{yr}^{-1}$ ) and mid-altitude catchments (altitude 1850-900 m, annual precipitation between 900 and $1800 \mathrm{~mm} \mathrm{yr}^{-1}$ ) to the lower semiarid Tana catchment (altitude $900-10 \mathrm{~m}$, annual precipitation between 450 and $900 \mathrm{~mm} \mathrm{yr}^{-1}$ ) (Brown and Schneider, 1998, Fig. 2b). The basin experiences a bimodal hydrological cycle, with long rains between March and May, and short rains between October and December, which also leads to a clear bimodal pattern in the river discharge (Fig. 3). The mean annual river discharge at the Garissa gauging station is $156 \mathrm{~m}^{3} \mathrm{~s}^{-1}$ over the period 1934 to 1975 (daily data from the Global River Discharge Database, available at http://daac.ornl.gov/RIVDIS/rivdis.shtml). The high-altitude headwaters (Aberdare Range, Mt Kenya) are characterised by mountainous forest vegetation and moorlands at the highest elevations, giving way to more intense agricultural activities in mid-altitude regions. The semiarid lower Tana is dominated by open to wooded savannah grassland, with some riverine gallery forests along the Tana River. 


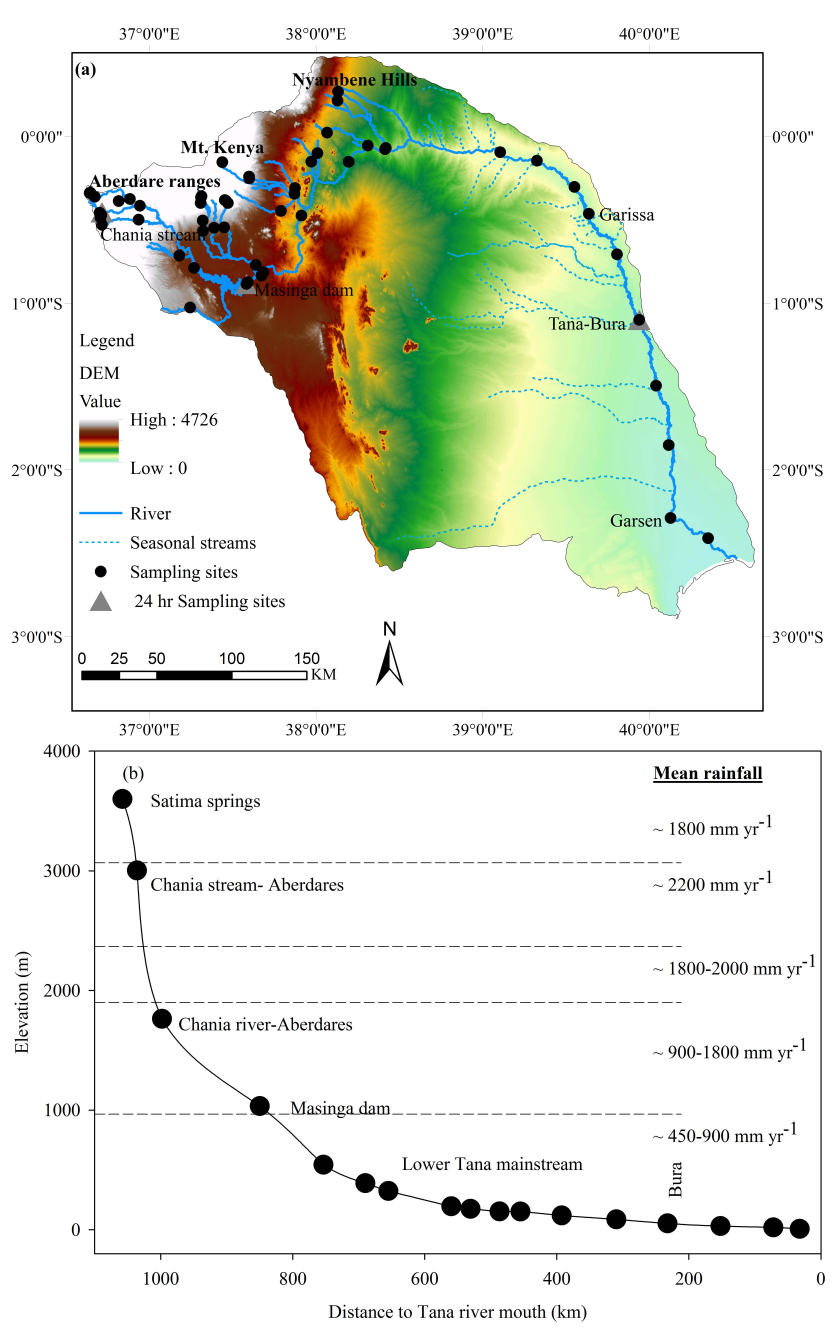

Fig. 2. (a) Digital elevation model (DEM) of the Tana River basin, which consists of two main geographical units - the Tana headwaters and the lower Tana mainstream. The 57 sampling sites are indicated by black dots. (b) Profile of the Tana River from headwaters to Tana mouth. Sampling stations for the lower Tana River are indicated, as well as a selected number of headwater sampling sites to show their overall position. Note: Chania Stream, Masinga Dam (close to intake) and Tana-Bura are $24 \mathrm{~h}$ cycle sampling sites.

\subsection{Sampling and analytical techniques}

Sampling was carried out during the three campaigns of February 2008 (dry season), September-November 2009 (wet season) and June-July 2010 (end of the wet season) (Fig. 3). The average river discharge measured at Garissa station during the wet season $\left(209 \mathrm{~m}^{3} \mathrm{~s}^{-1}\right)$ was 1.7 times higher than during the dry season $\left(123 \mathrm{~m}^{3} \mathrm{~s}^{-1}\right)$ and 1.4 times higher that of the end of the wet season $\left(145 \mathrm{~m}^{3} \mathrm{~s}^{-1}\right)$ (Fig. 3). Samples were taken throughout the river basin (Fig. 2a, Supplement Table 1); sampling sites included a subset of small streams in the headwater regions, an approximately equidistant set of locations along the lower Tana River mainstream,

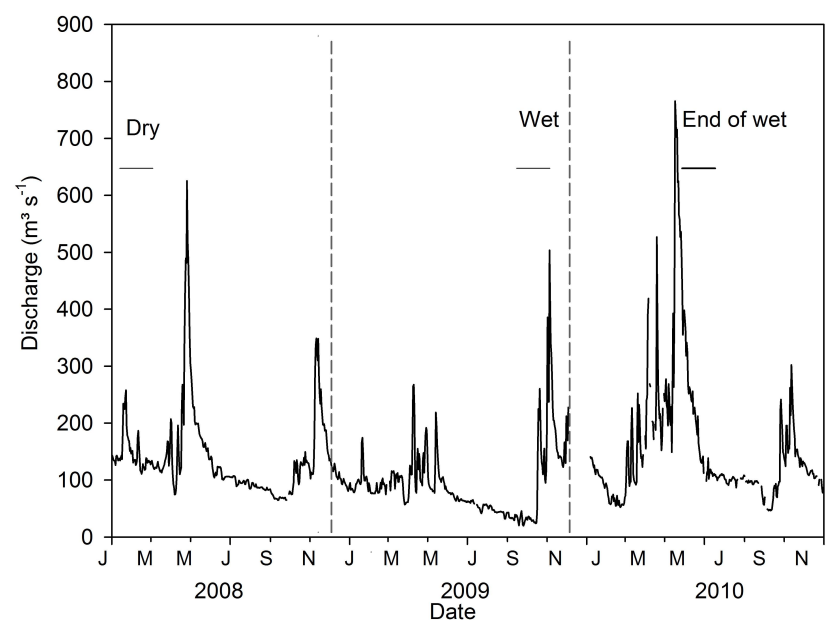

Fig. 3. Discharge measurements for the Tana River (2008-2010) as recorded at Garissa station. (Data source: Water Resource Management Authority.) Horizontal lines indicate the duration of the three field investigations, while vertical dashed lines separate different years. Dry season data have already been presented in Bouillon et al. (2009).

and depth profiles at two of the five hydroelectric reservoirs (Masinga and Kamburu). The dry season campaign in February 2008 only covered a subset of these field sites; these data have already been presented in Bouillon et al. (2009), and are used here for comparison purposes. In both the 2009 and 2010 campaigns, an extensive basin-wide survey was carried out. In addition, three sampling sites (Chania Stream in the Aberdare Range, Masinga Reservoir and the Tana River at Bura) were selected for a $24 \mathrm{~h}$ cycle sampling (Fig. 2a).

During the dry season and the wet season campaigns, water temperature and DO were measured in situ with a polarographic electrode (WTW Oxi-340) calibrated on saturated air, with an accuracy of $0.1 \%$, while $\mathrm{pH}$ was measured using a combined potentiometric electrode (Metrohm Thermo Orion model 230). A YSI ProPlus multimeter was used during the end of the wet season campaign. The $\mathrm{pH}$ probe was calibrated using United States National Bureau of Standards buffer solutions (4 and 7). Water samples for the analysis of $\delta^{13} \mathrm{C}_{\mathrm{DIC}}$ and $\delta^{18} \mathrm{O}_{\mathrm{DO}}$ were taken with a Niskin bottle at $\sim 0.5 \mathrm{~m}$ below the water surface by gently overfilling $12 \mathrm{~mL}$ glass headspace vials, and poisoned with $20 \mu \mathrm{L}$ of a saturated $\mathrm{HgCl}_{2}$ solution. For the analysis of $\delta^{13} \mathrm{C}_{\mathrm{DIC}}$, a $2 \mathrm{~mL}$ helium $(\mathrm{He})$ headspace was created, and $\mathrm{H}_{3} \mathrm{PO}_{4}$ was added to convert all DIC species to $\mathrm{CO}_{2}$. After overnight equilibration, part of the headspace was injected in the stream of an elemental analyser - isotope ratio mass spectrometer (EAIRMS: Thermo Finnigan Flash HT and Thermo Finnigan Delta $\mathrm{V}$ Advantage) for $\delta^{13} \mathrm{C}$ measurements. The obtained $\delta^{13} \mathrm{C}$ data were corrected for the isotopic equilibration between gaseous and dissolved $\mathrm{CO}_{2}$ as described in Gillikin and Bouillon (2007). Measurements were calibrated with 
certified reference materials LSVEC and either NBS-19 or IAEA-CO-1. For $\delta^{18} \mathrm{O}_{\mathrm{DO}}$, a similar headspace was created, after which samples were left to equilibrate for $2 \mathrm{~h} . \delta^{18} \mathrm{O}_{\mathrm{DO}}$ was then measured using the same EA-IRMS setup by monitoring $m / z$ 32, 33 and 34 and using a molecular sieve (5 column to separate $\mathrm{N}_{2}$ from $\mathrm{O}_{2}$. Outside air was used as the internal standard to correct all $\delta^{18} \mathrm{O}$ data.

Water samples for total alkalinity (TA) were obtained by prefiltering surface water through pre-combusted GF/F filters $(0.7 \mu \mathrm{m})$, with further filtration through $0.2 \mu \mathrm{m}$ syringe filters in high-density polyethylene bottles. TA was analysed by automated electro-titration on $50 \mathrm{~mL}$ samples with $0.1 \mathrm{~mol} \mathrm{~L}^{-1} \mathrm{HCl}$ as the titrant (reproducibility estimated as better than $\pm 3 \mu \mathrm{mol} \mathrm{kg}^{-1}$ based on replicate analyses). The partial pressure of $\mathrm{CO}_{2}\left(p \mathrm{CO}_{2}\right)$ and DIC concentrations were computed from $\mathrm{pH}$ and TA measurements using the carbonic acid dissociation constants for freshwater from Millero et al. (1979). The accuracy of computed DIC and $p \mathrm{CO}_{2}$ values was estimated at $\pm 5 \mu \mathrm{mol} \mathrm{L}{ }^{-1}$ and $\pm 5 \mathrm{ppm}$, respectively. Water samples for major elements and nutrient $\left(\mathrm{NO}_{3}^{-}\right)$were obtained in $20 \mathrm{~mL}$ scintillation vials in the same way as TA samples, but were preserved with $20 \mu \mathrm{L}$ of ultra-pure $\mathrm{HNO}_{3}$ and $20 \mu \mathrm{L}$ of a saturated $\mathrm{HgCl}_{2}$ solution for major elements and nutrients, respectively. The concentrations of major elements $(\mathrm{Ca}, \mathrm{Mg}, \mathrm{Na}, \mathrm{Si})$ were measured using inductively coupled plasma-atomic emission spectroscopy (Iris Advantage, Thermo Jarrel-Ash), while nutrients were measured using standard chromatographic techniques (ICS-900, Dionex).

Water-air $\mathrm{CO}_{2}$ fluxes were measured using a custommade floating chamber with a surface area and volume of approximately $0.045 \mathrm{~m}^{2}$ and $5.2 \mathrm{~L}$, respectively, coupled with an infrared $\mathrm{CO}_{2}$ analyser (Licor-820) and data logger. The floating chamber was placed on the surface of the water and kept stationary for $\sim 10 \mathrm{~min}$. The slope of the linear regression between $p \mathrm{CO}_{2}$ and time was obtained and used to calculate the $\mathrm{CO}_{2}$ flux per unit area and per unit time based on the equation

$F_{\mathrm{CO}_{2}}=\left(\mathrm{d} p \mathrm{CO}_{2} / \mathrm{d} t(V / R T S)\right.$,

where $\mathrm{d} p \mathrm{CO}_{2} / \mathrm{d} t$ is the slope of the $\mathrm{CO}_{2}$ accumulation in the chamber $\left(\mathrm{atm} \mathrm{s}^{-1}\right), V$ is the chamber volume $(\mathrm{L}), T$ is air temperature $(\mathrm{K}), S$ is the surface area of the chamber at the water surface $\left(\mathrm{m}^{2}\right)$ and $R$ is the gas constant $\left(\mathrm{L}\right.$ atm K $\left.{ }^{-1} \mathrm{~mol}^{-1}\right)$.

Samples for phytoplankton pigment analysis were obtained by filtering a known volume of surface water on pre-combusted $47 \mathrm{~mm} \mathrm{GF/F} \mathrm{filters,} \mathrm{which} \mathrm{were} \mathrm{immediately}$ packed into cryotubes and stored in liquid $\mathrm{N}_{2}$. Upon return to the laboratory, the samples were stored at $-20^{\circ} \mathrm{C}$ until further analysis. Pigments were extracted in $10 \mathrm{~mL}$ of an acetone: water mixture $(90: 10)$, and a subsample was separated by high-performance liquid chromatography on a C18 reverse-phase column. Calibration was performed with working standards prepared from commercially available pure compounds.
The $R$ rates were determined by quantifying the decrease in DO (using the polarographic electrode WTW Oxi-340) of river water incubated in a dark, cool box filled with water to retain ambient temperature for approximately $24 \mathrm{~h}$ using $250 \mathrm{~mL}$ bottles ( $2-3$ replicates) with airtight polyconic caps. The $P$ rates were quantified by determining the uptake of DIC after short-term $(1-3 \mathrm{~h})$ in situ incubations of river water during the day using $1 \mathrm{~L}$ polycarbonate bottle spiked with ${ }^{13} \mathrm{C}$-labelled sodium bicarbonate $\left(\mathrm{NaH}^{13} \mathrm{CO}_{3}\right)$. A subsample for $\delta^{13} \mathrm{C}_{\text {DIC }}$ of the spiked water was sampled for the purpose of computations. Samples for analysis of particulate organic carbon (POC) and $\delta^{13} \mathrm{C}_{\mathrm{POC}}$ were obtained at the start (natural abundance values) and at the end of the incubation by filtering a known volume of surface water on pre-combusted (overnight at $\left.450^{\circ} \mathrm{C}\right) 25 \mathrm{~mm} \mathrm{GF} / \mathrm{F}$ filters $(0.7 \mu \mathrm{m})$. Filters were decarbonated with $\mathrm{HCl}$ fumes for $4 \mathrm{~h}$, re-dried and then packed into Ag cups. POC and $\delta^{13} \mathrm{C}_{\mathrm{POC}}$ were determined on a Thermo elemental analyser - isotope ratio mass spectrometer (EA-IRMS) system (Flash HT with Delta V Advantage), using the TCD signal of the EA to quantify POC and by monitoring $m / z 44,45$ and 46 on the IRMS. Quantification and calibration of $\delta^{13} \mathrm{C}$ data were performed with IAEA-C6 and acetanilide that was calibrated against international standards. Reproducibility of $\delta^{13} \mathrm{C}_{\mathrm{POC}}$ measurements was typically better than $0.2 \%$. The $P$ data here refer only to surface water ( $\sim 0.5 \mathrm{~m}$ deep) measurements (not depth integrated). Calculations to quantify the rates were made as described in Dauchez et al. (1995).

\section{Results}

\subsection{In situ measurements, dissolved inorganic carbon and $\delta^{13} \mathrm{C}_{\text {DIC }}$}

Generally, temperature, $\mathrm{pH}$ and specific conductivity increased consistently downstream (Pearson correlation: $r^{2}=$ $0.90,0.41$ and 0.47 for temperature, $\mathrm{pH}$ and specific conductivity, respectively; $p<0.05 ; n=132$ ) with water temperature ranging from 10.6 to $32.1^{\circ} \mathrm{C}, \mathrm{pH}$ from 6.61 to 8.71 , specific conductivity from 11 to $582 \mu \mathrm{S} \mathrm{cm}^{-1}$ and DO from 41 to $134 \%$ during the 2008 dry season, 2009 wet season and 2010 end of the wet season campaigns (Supplement Table 1, Supplement Figs. 1 and 2). DIC concentrations ranged from 0.2 to $4.8 \mathrm{mmol} \mathrm{L}^{-1}$ with an overall mean of $1.1 \pm 1.0 \mathrm{mmol} \mathrm{L}^{-1}$. Exceptionally high values $\left(3.5 \pm 1.6 \mathrm{mmol} \mathrm{L}^{-1}\right)$ were systematically recorded in Nyambene Hills tributaries during all three campaigns (Fig. 4). DIC concentrations increased consistently downstream (Pearson correlation: $p<0.01, r^{2}=0.67 ; n=108$ ) when excluding values from Nyambene Hills tributaries. The DIC concentrations within different tributaries were similar (paired $t$ test, $p>0.05$ ) during the three campaigns. In contrast, DIC concentrations in the Tana River mainstream were significantly higher (ANOVA, $p<0.05$ ) during the 2009 wet 


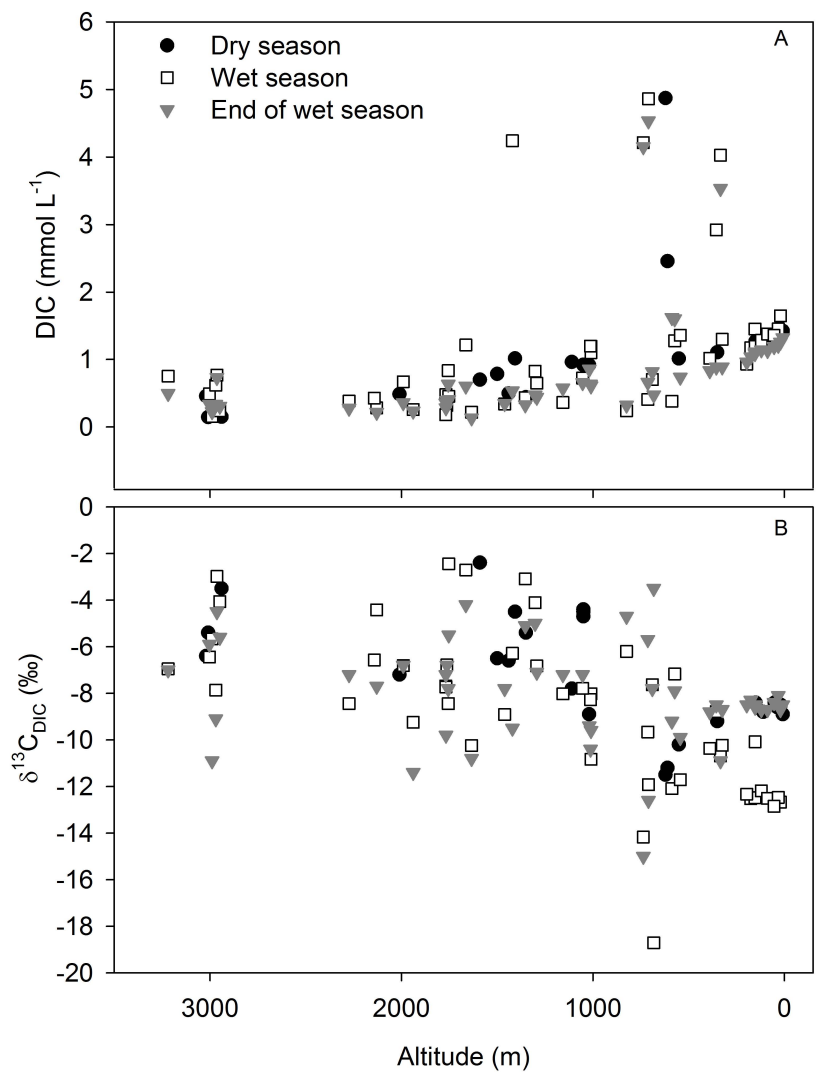

Fig. 4. Altitudinal profiles of (A) dissolved inorganic carbon concentrations and (B) $\delta^{13} \mathrm{C}_{\text {DIC }}$ along the Tana River basin during all three sampling seasons. Dry season data have already been presented in Bouillon et al. (2009).

season campaign $\left(1.3 \pm 0.2 \mathrm{mmol} \mathrm{L}^{-1}\right)$ and lowest during the 2010 end of the wet season campaign $\left(1.1 \pm 0.2 \mathrm{mmol} \mathrm{L}^{-1}\right)$.

$\delta^{13} \mathrm{C}_{\text {DIC }}$ signatures ranged from -20.8 to $-2.4 \%$ o during the three campaigns. $\delta^{13} \mathrm{C}_{\mathrm{DIC}}$ values within different tributaries were similar (paired $t$ test, $p>0.05$ ) during all three campaigns, but the Tana River mainstream recorded relatively depleted values $(-11.2 \pm 1.8 \%$ ) during the 2009 wet season campaign compared to the 2008 dry season and 2010 end of wet season campaigns combined $(-8.7 \pm 0.7 \%$ ). Overall, $\delta^{13} \mathrm{C}_{\text {DIC }}$ showed a negative correlation with DIC concentrations (Pearson correlation: $p<0.01, r^{2}=0.49$; $n=122$ ) during all three campaigns, with tributaries from the Aberdare and Mt Kenya regions recording the lowest DIC concentrations $\left(0.6 \pm 0.3 \mathrm{mmol} \mathrm{L}^{-1}\right)$ and highest $\delta^{13} \mathrm{C}_{\mathrm{DIC}}$ signatures $(-6.9 \pm 2.7 \% 0)$ and the Tana River mainstream intermediate DIC concentrations $\left(1.2 \pm 0.2 \mathrm{mmol} \mathrm{L}^{-1}\right)$ and $\delta^{13} \mathrm{C}_{\mathrm{DIC}}$ signatures $(-9.7 \pm 1.7 \%$ ), whereas Nyambene Hills tributaries recorded the highest DIC concentrations $\left(3.5 \pm 1.6 \mathrm{mmol} \mathrm{L}^{-1}\right)$ and the lowest $\delta^{13} \mathrm{C}_{\mathrm{DIC}}$ signatures $(-11.3 \pm 2.4 \%)$. Substantially higher $\delta^{13} \mathrm{C}_{\mathrm{DIC}}$ values were observed at Masinga Reservoir $(-4.5 \pm 0.1 \%$ ) during the dry season, but this decreased rapidly to $-8.9 \%$ less than $5 \mathrm{~km}$ downstream.

\subsection{Dynamics of riverine $p \mathrm{CO}_{2}$ and $\mathrm{CO}_{2}$ fluxes}

The whole river network, with a few exceptions, was supersaturated with $\mathrm{CO}_{2} \quad\left(p \mathrm{CO}_{2}\right.$ values between 110 and $5204 \mathrm{ppm}$ ) with respect to atmospheric equilibrium (385 ppm), with an overall median of $1002 \mathrm{ppm}$. Higher values were recorded during the 2009 wet season campaign (median $1432 \mathrm{ppm}$ ) compared to the 2010 end of the wet season (median $1002 \mathrm{ppm}$ ), whereas the 2008 dry season was two-fold lower (median $579 \mathrm{ppm}$, Fig. 5). Tributaries from the Aberdare and Mt Kenya regions recorded low $p \mathrm{CO}_{2}$ concentrations (median $867 \mathrm{ppm}$ ) compared to those from Nyambene Hills tributaries and the Tana River mainstream (median 1220 ppm, ANOVA $p<0.05$, Fig. 6b). During the 2009 wet season campaign, tributaries from Mt Kenya region recorded higher $p \mathrm{CO}_{2}$ concentrations ( $t$ test, $p<0.05$ ), particularly those in mid-altitude catchments (1850-900 m), characterised by intensive agricultural practises. During the 2009 wet season campaign, sampling at Kamburu Dam was done shortly before the actual onset of the wet season. Surface waters were highly undersaturated in $\mathrm{CO}_{2}$ during both the wet $\left(p \mathrm{CO}_{2}=118 \mathrm{ppm}\right)$ and end of the wet season campaigns $\left(p \mathrm{CO}_{2}=305 \mathrm{ppm}\right)$. Surface waters of Masinga Reservoir were similarly undersaturated in $\mathrm{CO}_{2}$ during the 2008 dry season campaign ( $p \mathrm{CO}_{2}$ from 313 to $443 \mathrm{ppm}$, Bouillon et al., 2009) but relatively oversaturated in $\mathrm{CO}_{2}$ during the end of the wet season campaign $\left(p \mathrm{CO}_{2}\right.$ from 2629 to $3389 \mathrm{ppm}$ ). However, $p \mathrm{CO}_{2}$ was elevated downstream of the Masinga Reservoir exit (2303 to 5204 ppm at Tana RiverMasinga Bridge) during all three campaigns, but the concentrations decreased rapidly downstream (Supplement Table 1). $p \mathrm{CO}_{2}$ showed a negative correlation with $\delta^{13} \mathrm{C}_{\mathrm{DIC}}$ values (Pearson correlation: $p<0.01, r^{2}=0.52 ; n=125$; Fig. 6a) during all three campaigns.

$\mathrm{CO}_{2}$ fluxes between the river and the atmosphere based on floating chamber measurements ranged from -12.4 to $639.0 \mathrm{mmol} \mathrm{m}^{-2} \mathrm{~d}^{-1}$ during the wet season campaign and from -57.1 to $813.7 \mathrm{mmol} \mathrm{m}^{-2} \mathrm{~d}^{-1}$ during the end of the wet season campaign. The $\mathrm{CO}_{2}$ fluxes were similar during the two seasons (Paired $t$ test, $p>0.05$ ). Similar to $p \mathrm{CO}_{2}$, disproportionately high water-air evasion was recorded during the end of the wet season campaign downstream of Masinga Reservoir exit (Masinga Bridge, $600 \mathrm{mmol} \mathrm{m}^{-2} \mathrm{~d}^{-1}$ ). On average, Nyambene Hills tributaries recorded the highest $\mathrm{CO}_{2}$ evasion $\left(-4.2\right.$ to $\left.617 \mathrm{mmol} \mathrm{m}^{-2} \mathrm{~d}^{-1}\right)$ during both seasons (Fig. 7) corresponding with higher $p \mathrm{CO}_{2}$ values (806 to $4915 \mathrm{ppm})$. Generally, $\mathrm{CO}_{2}$ fluxes showed a positive correlation with $p \mathrm{CO}_{2}$ (Pearson correlation: $p<0.01, r^{2}=0.61$; $n=76$ ). 


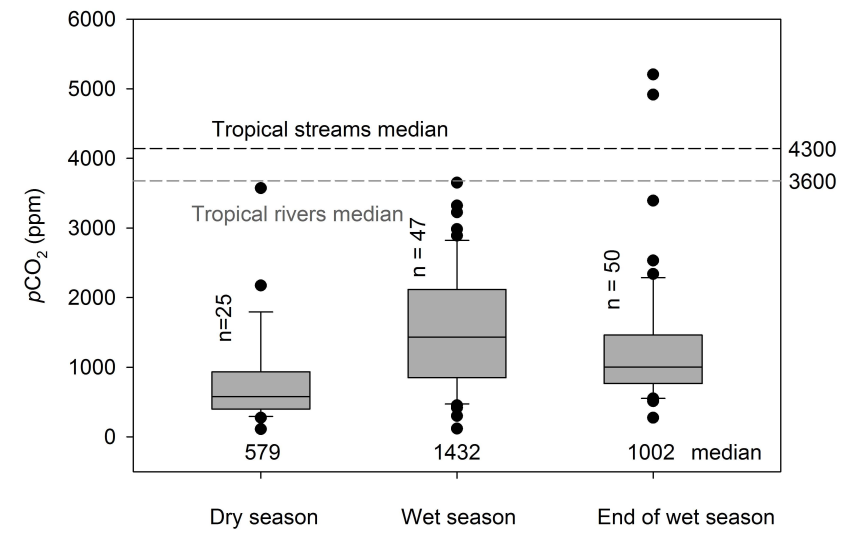

Fig. 5. Boxplots of $p \mathrm{CO}_{2}$ during the three sampling campaigns. The centre line, box extent, error bars, and dots denote the 50th percentile, 25th and 75th percentiles, 10th and 90th percentiles, and outliers of estimates, respectively. Horizontal dashed lines represent tropical medians for rivers and streams (Aufdenkampe et al., 2011).

\subsection{Nitrate, chlorophyll $a$, primary production and respiration measurements}

Nitrate concentrations ranged from 0.4 to $146 \mu \mathrm{mol} \mathrm{L}^{-1}$ during all three seasons (Supplement Table 2). The concentrations increased consistently downstream during both the wet season (Pearson correlation: $p<0.01, r^{2}=0.75 ; n=50$ ) and end of the wet season (Pearson correlation: $p<0.01$, $r^{2}=0.50 ; n=50 ;$ Fig. $8 \mathrm{~b}$ ), but during the dry season, nitrate did not show a systematic pattern with altitude. The highest mean concentrations ( 78.6 to $96.3 \mu \mathrm{mol} \mathrm{L}^{-1}$ ) were recorded in Nyambene Hills tributaries during all three seasons.

Chlorophyll $a$ concentration ranged from 0.18 to $9.60 \mu \mathrm{g} \mathrm{L}^{-1}$ with means of $2.74 \pm 2.52,1.94 \pm 1.94$ and $2.20 \pm 2.75 \mu \mathrm{g} \mathrm{L}^{-1}$ during the dry season, the wet season and end of the wet season respectively (Supplement Table 2). The chlorophyll $a$ concentration increased consistently downstream (Pearson correlation: $p<0.01, r^{2}=0.55 ; n=117$; Fig. 9b), and values during different seasons were not significantly different (paired $t$ test, $p>0.05$ ). Elevated chlorophyll $a$ concentrations ( 3.2 to $20.6 \mu \mathrm{g} \mathrm{L}^{-1}$ ) were recorded in the Kamburu and Masinga reservoirs during all three sampling campaigns.

The primary production rates ranged from 0.004 to $7.38 \mu \mathrm{mol} \mathrm{CL}^{-1} \mathrm{~h}^{-1}$ with means of $0.42 \pm 0.46$ and $0.83 \pm 1.58 \mu \mathrm{mol} \mathrm{CL}^{-1} \mathrm{~h}^{-1}$ for the wet and the end of the wet season campaign, respectively. The primary production rates increased consistently downstream (Pearson correlation: $r^{2}=0.55, p<0.01 ; n=84$; Fig. 9a) during both campaigns. Disproportionately high values ranging between 10.28 and $18.28 \mu \mathrm{mol} \mathrm{CL}^{-1} \mathrm{~h}^{-1}$ were recorded in the Kamburu and Masinga reservoirs (Supplement Table 2). The means for different seasons were similar (paired $t$ test, $p>0.05$ ), but Mt Kenya and Nyambene Hills tributaries recorded significantly higher values $(0.19 \pm 0.22$ and
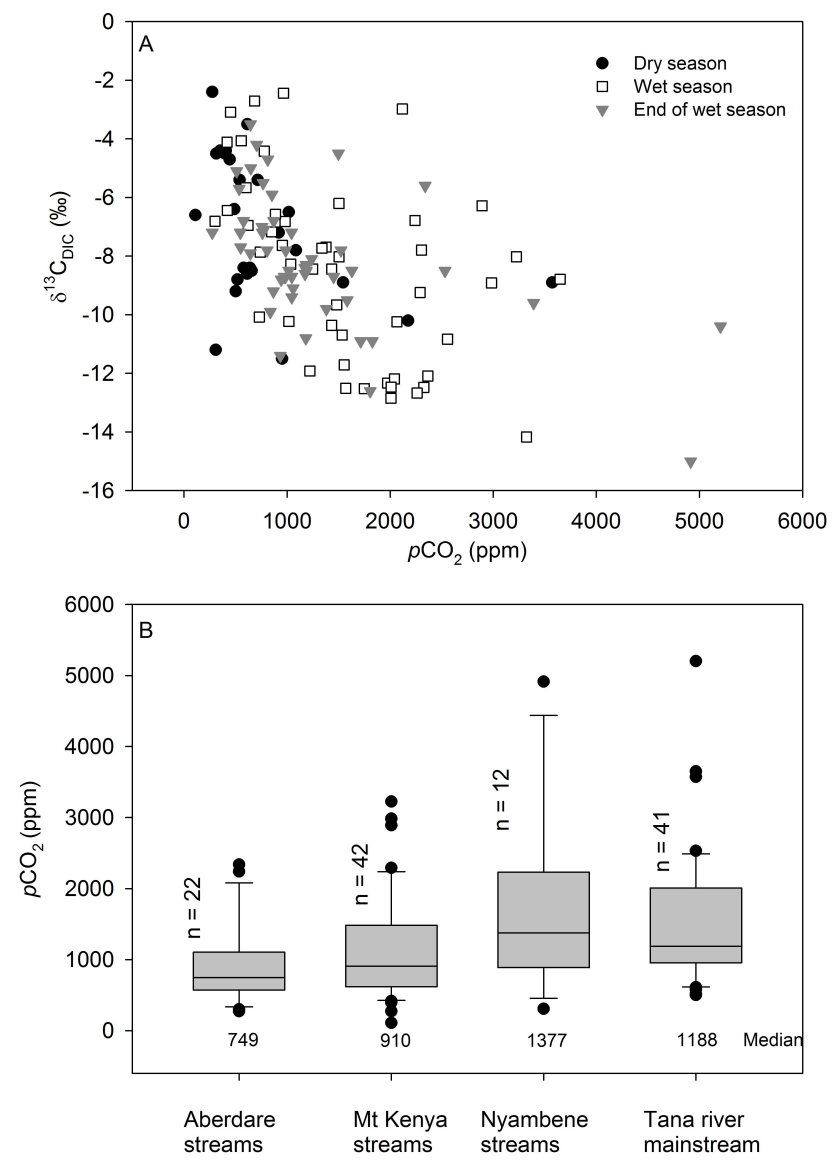

Fig. 6. (A) Plot of $\delta^{13} \mathrm{C}_{\mathrm{DIC}}$ vs. $p \mathrm{CO}_{2}$ along the Tana River basin, (B) Boxplots of $p \mathrm{CO}_{2}$ along the Tana River basin. The centre line, box extent, error bars, and dots denote the 50th percentile, 25th and 75 th percentiles, 10th and 90th percentiles, and outliers of estimates, respectively.

$0.79 \pm 0.45 \mu \mathrm{molC} \mathrm{L}^{-1} \mathrm{~h}^{-1}$, respectively) during the 2009 wet season campaign (paired $t$ test, $p<0.05$ ) compared to the 2010 end of the wet season campaign $(0.07 \pm 0.07$ and $0.26 \pm 0.28 \mu \mathrm{mol} \mathrm{C} \mathrm{L}{ }^{-1} \mathrm{~h}^{-1}$, respectively).

Riverine $R$ rates were measured only during the 2009 wet season campaign and ranged from $0.20 \pm 0.07$ to $3.64 \pm 0.03 \mu \mathrm{mol} \mathrm{O}_{2} \mathrm{~L}^{-1} \mathrm{~h}^{-1}$ with a basin-wide mean of $1.43 \pm 0.91 \mu \mathrm{mol} \mathrm{O}_{2} \mathrm{~L}^{-1} \mathrm{~h}^{-1}$ (Supplement Table 2). The $R$ rates increased downstream (Pearson correlation: $p<$ $0.01, r^{2}=0.38 ; n=33$; Fig. $\left.8 \mathrm{a}\right)$, with Aberdare and Nyambene Hills tributaries recording the lowest mean $\left(0.84 \pm 0.84 \mu \mathrm{mol} \mathrm{O}_{2} \mathrm{~L}^{-1} \mathrm{~h}^{-1}\right)$ and Mt Kenya tributaries an intermediate one $\left(1.37 \pm 0.90 \mu \mathrm{mol} \mathrm{O}_{2} \mathrm{~L}^{-1} \mathrm{~h}^{-1}\right)$, while the lower Tana River mainstream stretch had the highest $\left(1.92 \pm 0.72 \mu \mathrm{mol} \mathrm{O}_{2} \mathrm{~L}^{-1} \mathrm{~h}^{-1}\right)$. The $R$ rates also showed a positive correlation with temperature (Pearson correlation: $r^{2}=0.46, p<0.01 ; n=33$ ). 


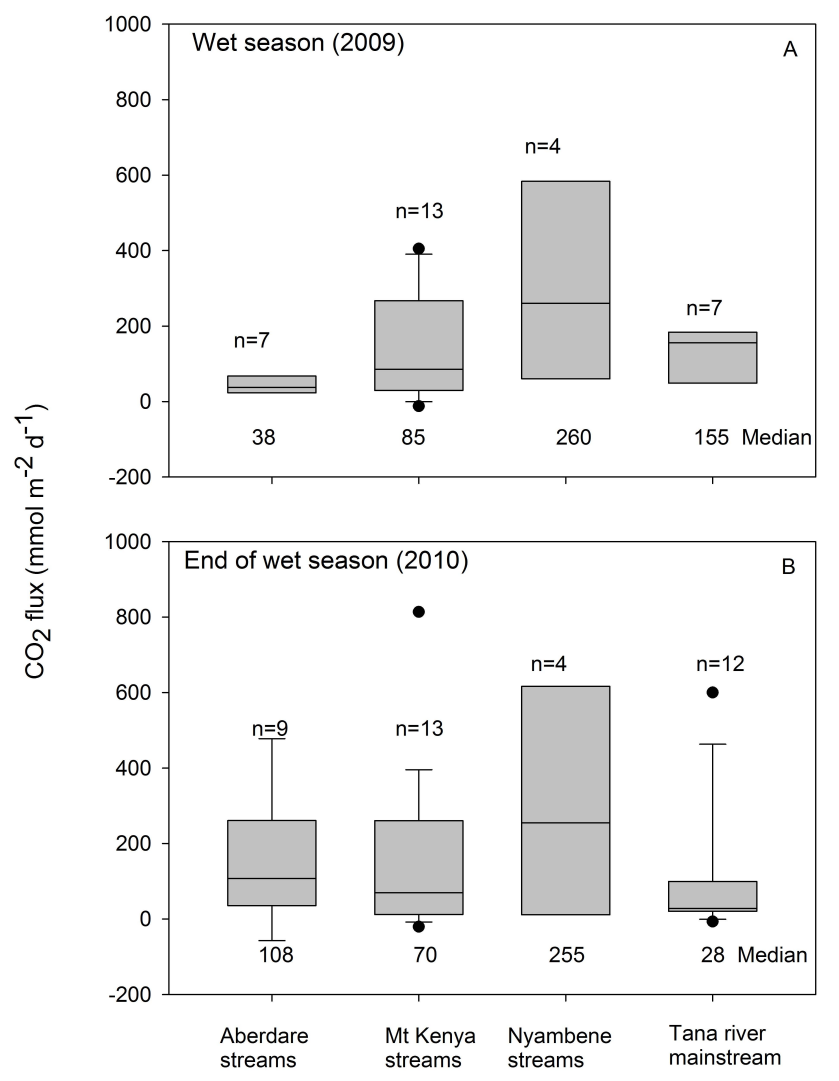

Fig. 7. Boxplots of $\mathrm{CO}_{2}$ effluxes along the Tana River basin during (A) the wet season, (B) end of the wet season. The centre line, box extent, error bars, and dots denote the 50th percentile, 25th and 75th percentiles, 10th and 90th percentiles, and outliers of estimates, respectively.

\subsection{Diurnal biogeochemical processes}

During the diurnal cycles, water temperature fluctuated by $9.7\left(6.9-16.6^{\circ} \mathrm{C}\right), 2.1\left(21.8-23.9^{\circ} \mathrm{C}\right)$ and $1.5^{\circ} \mathrm{C}(24.6-$ $\left.26.1^{\circ} \mathrm{C}\right)$, while $\mathrm{pH}$ fluctuated by $\sim 0.58(7.67-8.25), 0.14$ (6.98-7.12) and 0.05 units (7.83-7.88) at Chania Stream, Masinga Dam and Tana River mainstream, respectively (Table 1). The DO saturation fluctuated by 34.6 (89.4$124.0 \%), 10.6(63.0-73.6 \%)$ and $3.2 \%(96.7-99.9 \%)$ at Chania Stream, Masinga Dam and Tana River mainstream, respectively (Table 1). The in situ field measurements of $\mathrm{pH}$, temperature and DO increased steadily during daytime and decreased at night at Chania Stream (Fig. 10), while no discernible trends were observed at Masinga Dam and the Tana River mainstream.

$\delta^{18} \mathrm{O}_{\mathrm{DO}}$ signatures at Chania Stream ranged from +22.5 to $+25.5 \%$ (Supplement Table 3), with a diurnal mean of $+24.0 \pm 0.8 \%$. Although the magnitude of change was small, the values decreased during day time and increased at night time (Fig. 10). $\delta^{18} \mathrm{O}_{\mathrm{DO}}$ signatures showed a strong negative correlation with DO saturation (Pearson correlation:
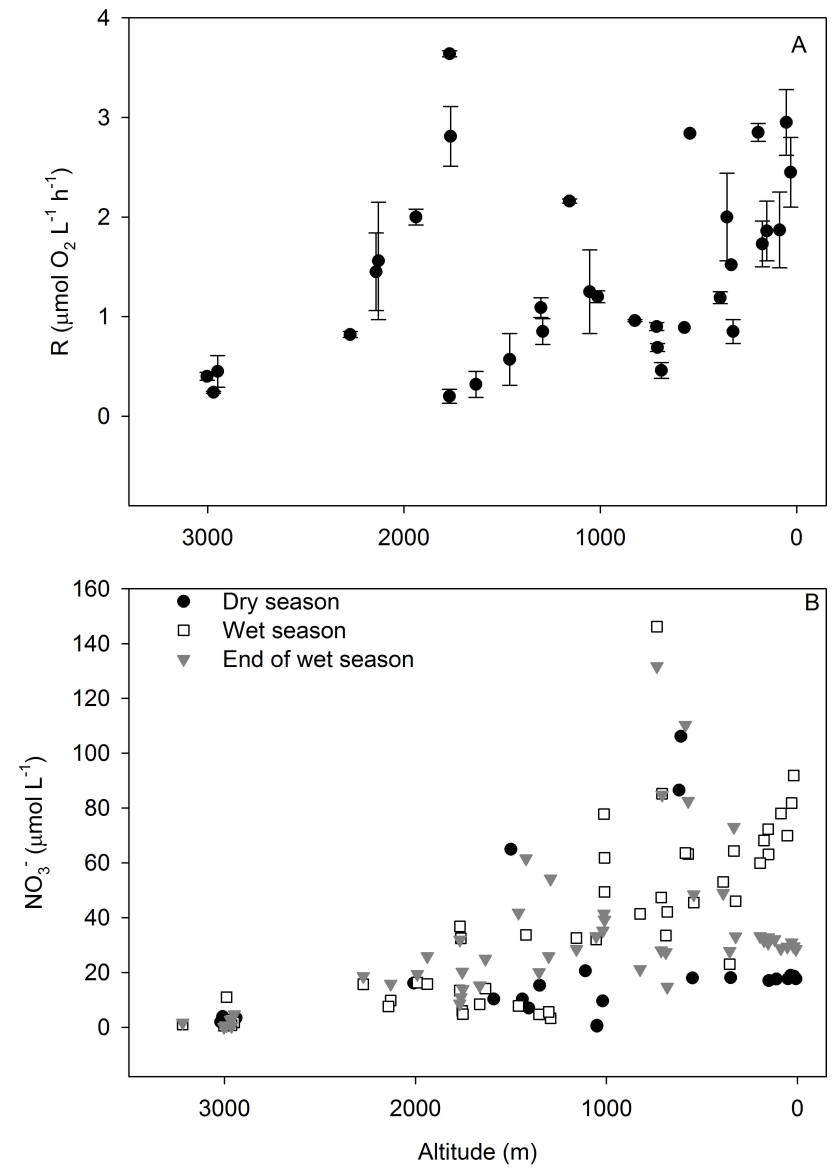

Fig. 8. Altitudinal profile of (A) respiration rate during the 2009 wet season, and (B) nitrate concentrations along the Tana River basin during the three sampling seasons.

$p<0.01, r^{2}=0.84 ; n=23$; Fig. 11a). Masinga Dam values $(+25.4$ to $+28.2 \%$ o) showed moderate diurnal fluctuation, while the Tana River mainstream $(+24.6$ to $+25.5 \%$ ) values did not exhibit clear diurnal fluctuations. The $\delta^{18} \mathrm{O}_{\mathrm{DO}}$ values at both the Masinga Dam and Tana River mainstream remained above the atmospheric equilibrium $(+24.2 \%)$ during the whole diurnal cycle, but values at Chania Stream oscillated above and below atmospheric equilibrium, though with a pronounced diurnal cycle (Fig. 10b). The maximum $\delta^{18} \mathrm{O}_{\mathrm{DO}}$ value $(+25.5 \%$ ) at Chania Stream was recorded at 04:00 LT (all times mentioned are in local time) corresponding with lowest DO saturation $(90.8 \%)$. Generally, $\delta^{18} \mathrm{O}_{\mathrm{DO}}$ values at Chania Stream were below atmospheric equilibrium $(+24.2 \%$ ) during daytime (07:00 to 17:00) and above atmospheric equilibrium at night (18:00 to 06:00).

The DIC values during the diurnal cycles ranged from 0.506 to $0.573 \mathrm{mmol} \mathrm{L}^{-1}, 0.603$ to $0.719 \mathrm{mmol} \mathrm{L}^{-1}$, and 1.152 to $1.224 \mathrm{mmol} \mathrm{L}^{-1}$, whereas $\delta^{13} \mathrm{C}_{\text {DIC }}$ ranged from -7.2 to $-5.8 \%$, -10.4 to $-9.6 \%$, and -8.9 to $-8.0 \%$ o for Chania Stream, Masinga Dam and the Tana River mainstream, respectively (Supplement Table 3). The latter two 

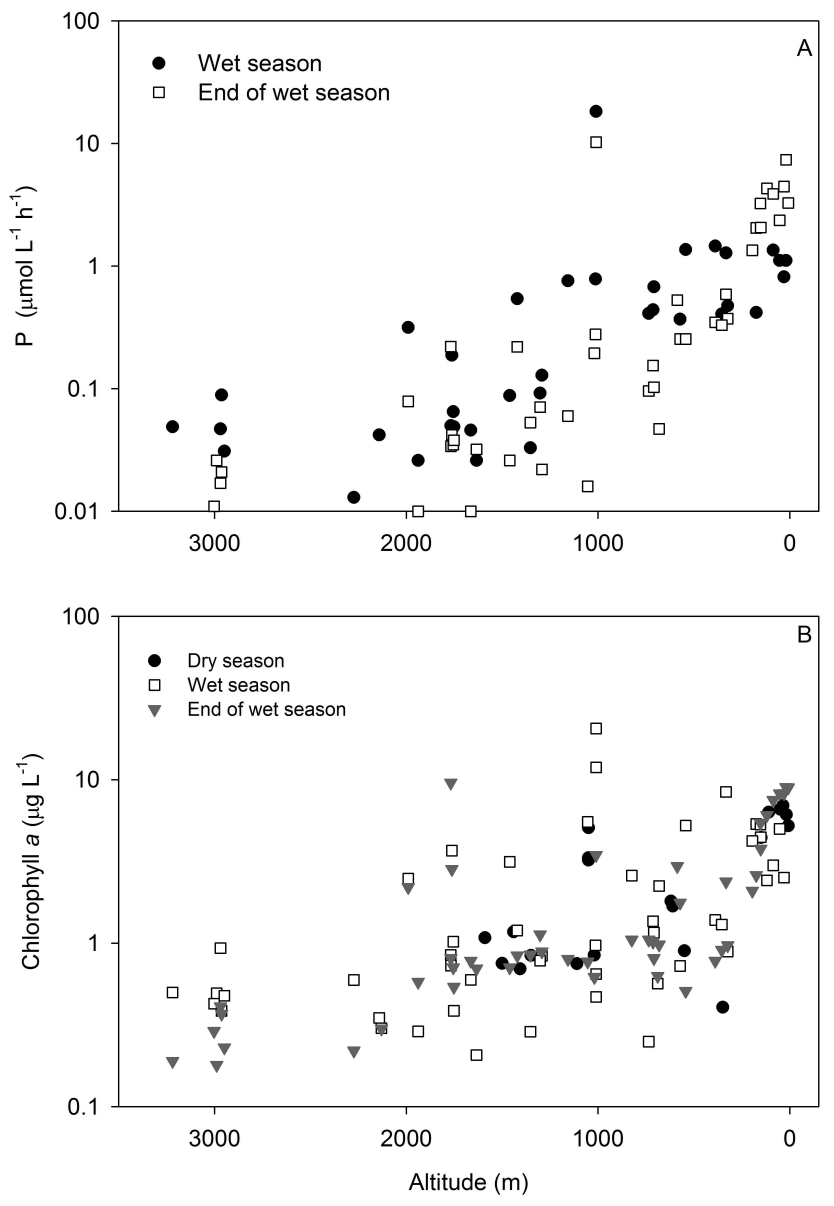

Fig. 9. Altitudinal profile of (A) primary production and (B) chlorophyll $a$ along the Tana River basin during different sampling seasons.

sites showed minimal $\delta^{13} \mathrm{C}_{\text {DIC }}$ diurnal amplitude $(\sim 0.9 \%$ o) compared to Chania Stream $(1.4 \%)$ ). $\delta^{13} \mathrm{C}_{\text {DIC }}$ values at Chania Stream typically increased during daytime and decreased at night (Fig. 12a). While the amplitudes of both DIC and $\delta^{13} C_{\text {DIC }}$ at Chania Stream were small, their diurnal cycles were pronounced but showed reversed patterns (Fig. 12a). In contrast, both the Masinga Dam and Tana River mainstream did not exhibit clear diurnal patterns for either $\delta^{13} \mathrm{C}_{\text {DIC }}$ or DIC. However, the DIC concentrations at the Tana River mainstream $\left(1.191 \pm 0.020 \mathrm{mmol} \mathrm{L}^{-1}\right)$ were significantly high (ANOVA, $p<0.01$ ) compared to those of Chania Stream $\left(0.547 \pm 0.021 \mathrm{mmol} \mathrm{L}^{-1}\right)$ and Masinga Reservoir $\left(0.666 \pm 0.027 \mathrm{mmol} \mathrm{L}^{-1}\right)$.

During the diurnal cycles, $p \mathrm{CO}_{2}$ values ranged from 174 to $614 \mathrm{ppm}, 2621$ to $3684 \mathrm{ppm}$, and 980 to $1131 \mathrm{ppm}$ at Chania Stream, Masinga Dam and Tana River mainstream, respectively (Supplement Table 3). $p \mathrm{CO}_{2}$ showed systematic diurnal fluctuations at Chania Stream, increasing consistently at night above the atmospheric equilibrium (385 ppm) to a maximum of $614 \mathrm{ppm}$ at 22:00 (Fig. 13a). From 06:00,
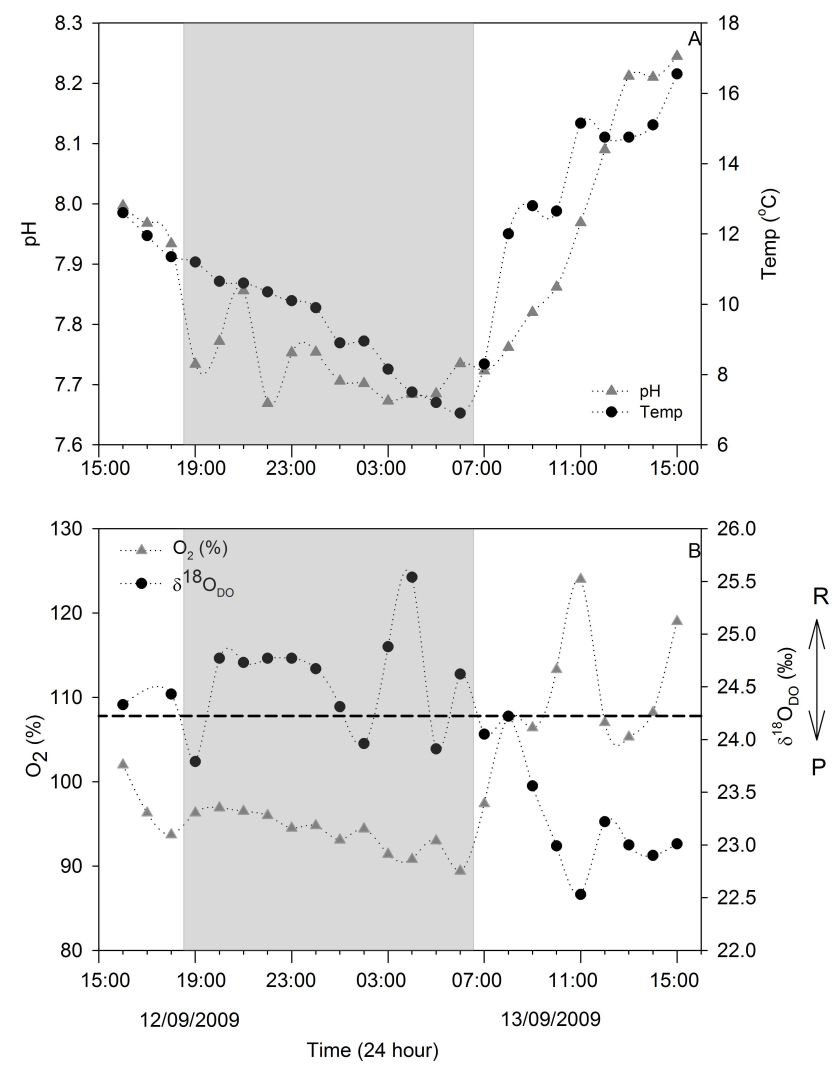

Fig. 10. Diurnal fluctuations of (A) $\mathrm{pH}$ and temperature, and (B) $\delta^{18} \mathrm{O}-\mathrm{DO}$ and $\%$ saturation of dissolved oxygen at Chania Stream. Night-time is indicated in grey.

the $p \mathrm{CO}_{2}$ values started to decrease, attaining a minimum plateau of $\sim 180 \mathrm{ppm}$ at 13:00. In contrast, $p \mathrm{CO}_{2}$ values at Masinga Dam (2621 to $3684 \mathrm{ppm}$ ) and Tana River mainstream (980 to $1131 \mathrm{ppm}$ ) were consistently above atmospheric equilibrium (385 ppm) during the whole diurnal cycle, with no clear diurnal fluctuation pattern. Similarly, $\mathrm{CO}_{2}$ fluxes ranged from -52 to $41 \mathrm{mmol} \mathrm{m}^{-2} \mathrm{~d}^{-1}, 95$ to $331 \mathrm{mmol} \mathrm{m}^{-2} \mathrm{~d}^{-1}$, and 2 to $16 \mathrm{mmol} \mathrm{m}^{-2} \mathrm{~d}^{-1}$ at Chania Stream, Masinga Dam and Tana River mainstream, respectively (Supplement Table 3). $\mathrm{CO}_{2}$ fluxes and $p \mathrm{CO}_{2}$ showed an identical diurnal pattern at Chania Stream (Fig. 13a), but $\mathrm{CO}_{2}$ fluxes at Masinga Dam and Tana River mainstream were consistently high throughout diurnal cycle and did not exhibit clear diurnal patterns.

The gas transfer velocity (k600) computed from the flux $\mathrm{CO}_{2}$ and the air-water $p \mathrm{CO}_{2}$ gradient was on average much higher at Chania Stream $\left(25.6 \pm 13.0 \mathrm{~cm} \mathrm{~h}^{-1}\right)$ than at Masinga Reservoir $\left(7.7 \pm 2.4 \mathrm{~cm} \mathrm{~h}^{-1}\right)$ and at Tana River at Bura $\left(1.3 \pm 0.4 \mathrm{~cm} \mathrm{~h}^{-1}\right)$ (Supplement Table 3). 

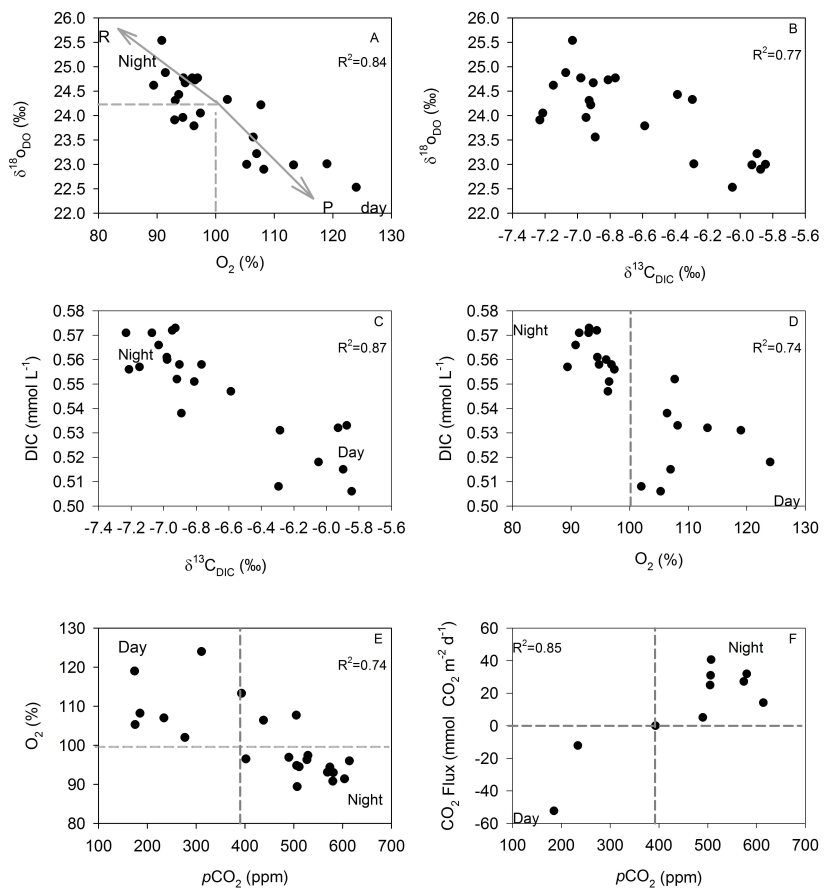

Fig. 11. Cross-plots showing behaviour of different biogeochemical parameters during the diurnal cycle at Chania Stream between 12 and 13 September 2009.

\section{Discussion}

\subsection{Longitudinal patterns of dissolved inorganic carbon and $\delta^{13} \mathrm{C}_{\mathrm{DIC}}$}

In the Tana River basin, DIC generally increased downstream during all three seasons, a strong indication of DIC buildup possibly contributed by rock weathering. This is particularly evident along the Tana River mainstream, where DIC strongly increased downstream during all seasons (Fig. 4a), which corresponded to an increase in suspended matter (Bouillon et al., 2009; Tamooh et al., 2012). Nyambene Hills tributaries recorded exceptionally high DIC concentrations (Fig. 4a) during all three seasons, a phenomenon we associate with a high rate of rock weathering. The lithology of the Nyambene Hills subcatchment mainly includes Quaternary volcanic rocks. The high rate of chemical weathering could result from the presence of ashes and pyroclastic rocks, as these have much higher weathering rates than basalts and trachytes (Hughes et al., 2012). $\mathrm{HCO}_{3}^{-}$in rivers is mainly derived from the weathering of carbonate and silicate rocks. The relative proportion of $\mathrm{HCO}_{3}^{-}$in rivers derived from weathering of carbonate and silicate rocks depends to a very large extent on the lithology of the drainage basin (Garrels and Mackenzie 1971; Meybeck 1987). In Kenya, sedimentary carbonate rocks are associated with the Mozambique Belt, south of the Tana drainage basin (Warden and Horkel 1984). The Tana drainage basin is rich in silicate
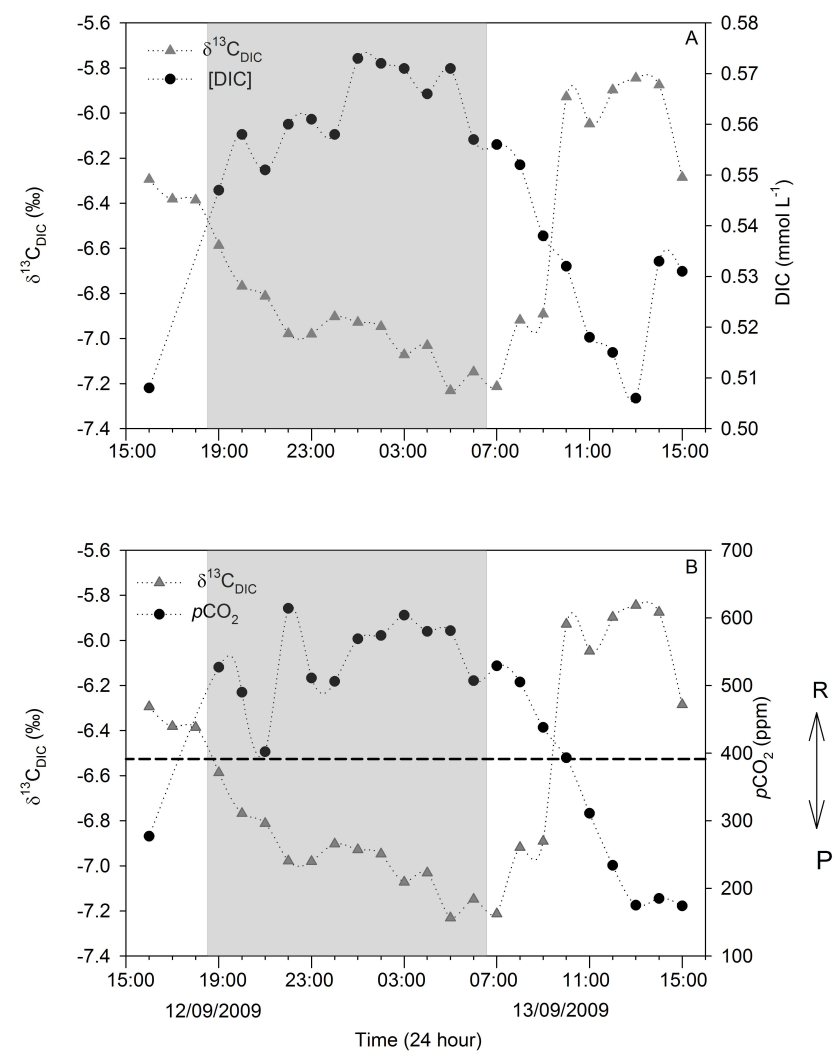

Fig. 12. Diurnal fluctuations of (A) $\delta^{13} \mathrm{C}_{\mathrm{DIC}}$ and DIC concentrations, and (B) $\delta^{13} \mathrm{C}_{\mathrm{DIC}}$ and $p \mathrm{CO}_{2}$ at Chania Stream. Night-time is indicated in grey.

rocks as it is mainly composed of Tertiary and Quaternary volcanic rocks, mainly basalt and a broad spectrum of alkaline rocks (e.g. Baker, 1987). Also, Kenya is extremely rich in alkaline rocks and carbonates (Woolley, 2001), including calcite carbonate (Rosatelli et al., 2003). Finally, saline and sodic soils characterise the dry lands in Kenya (Dijkshoorn et al., 2010), and the latter soils are rich in carbonates.

TA is well correlated with dissolved silicate (DSi) and the sum of $\mathrm{Ca}^{2+}$ and $\mathrm{Mg}^{2+}$ (Fig. 14), suggesting that $\mathrm{HCO}_{3}^{-}$ in the Tana originates from both carbonate and silicate rock weathering. The strong correlation between $\mathrm{TA}$ and $\mathrm{Na}^{+}$provides additional evidence for silicate weathering, which is the main source of $\mathrm{Na}^{+}$in rivers (data not shown). To discriminate the origin of $\mathrm{HCO}_{3}^{-}$, we applied the simple stoichiometric model of Garrels and Mackenzie (1971), whereby the contribution to TA from carbonate weathering $\left(\mathrm{TA}_{\text {carb }}\right)$ is computed from $\mathrm{Ca}^{2+}$ and $\mathrm{Mg}^{2+}$, and the contribution to TA from silicate weathering $\left(\mathrm{TA}_{\text {sil }}\right)$ is computed from DSi according to

$\mathrm{TA}_{\text {carb }}=2 \times\left(\left[\mathrm{Ca}^{2+}\right]+\left[\mathrm{Mg}^{2+}\right]-\left[\mathrm{SO}_{4}^{2-}\right]\right)$,

$\mathrm{TA}_{\text {sil }}=[\mathrm{DSi}] / 2$. 

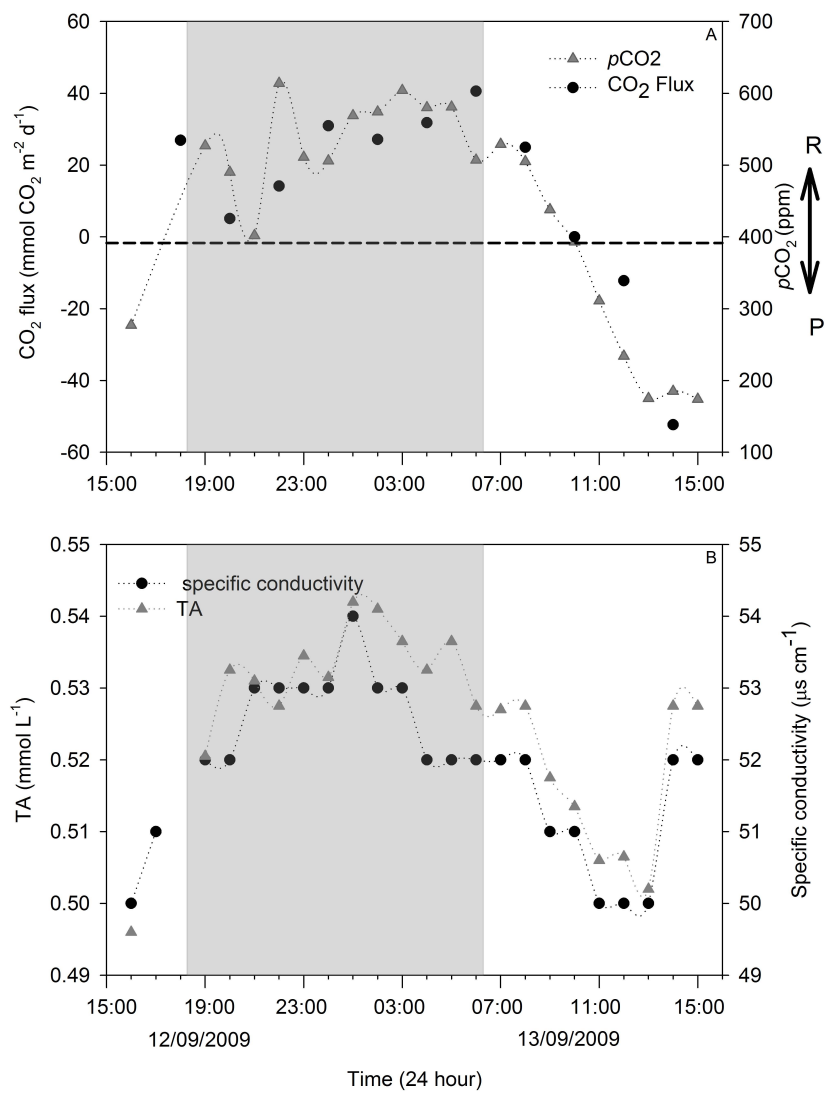

Fig. 13. Diurnal fluctuations of (A) $\mathrm{CO}_{2}$ effluxes and $p \mathrm{CO}_{2}$ and (B) TA and specific conductivity at Chania Stream. Night-time is indicated in grey.

$\mathrm{SO}_{4}^{2-}$ allows for $\mathrm{Ca}$ originating from the dissolution of gypsum $\left(\mathrm{CaSO}_{4}\right)$ to be accounted for. However, $\mathrm{SO}_{4}^{2-}$ data were only available for the 2009 wet season campaign, so we did not apply this correction. For the 2009 wet season campaign, $\mathrm{SO}_{4}^{2-}$ corresponded on average to $11 \%$ of $\mathrm{Ca}^{2+}$. The resulting estimated relative contributions of silicate weathering to total rock weathering ranges between 7 and $78 \%$ and averages $28 \%$, close to the overall average of $24 \%$ for African rivers reported by Garrels and Mackenzie (1971). Modelled $\mathrm{TA}\left(\mathrm{TA}_{\text {carb }}+\mathrm{TA}_{\text {sil }}\right)$ is very close to measured $\mathrm{TA}$, as most data points fall on the $1: 1$ line, with the exception of eight outliers (Fig. 15), which are mostly from the three rivers in the Nyambene Hills (Murera, Rojewero and Mutundu).

As previously reported by Hughes et al. (2012), the Nyambene Hills region is characterised by high silicate weathering, with DSi values up to $1148 \mu \mathrm{mol} \mathrm{L}^{-1}$ (Supplement Table 1), above the maximum of $958 \mu \mathrm{mol} \mathrm{L}^{-1}$ previously reported by Hughes et al. (2012). In the absence of detailed lithological information of the drainage basin in Nyambene Hills, it is difficult to explain the discrepancy between modelled and observed TA. Precipitation of hydrous sodium silicates and zeolites (Sebag et al., 2001) could explain the discrepancy because it would lead to a removal of DSi but leav-

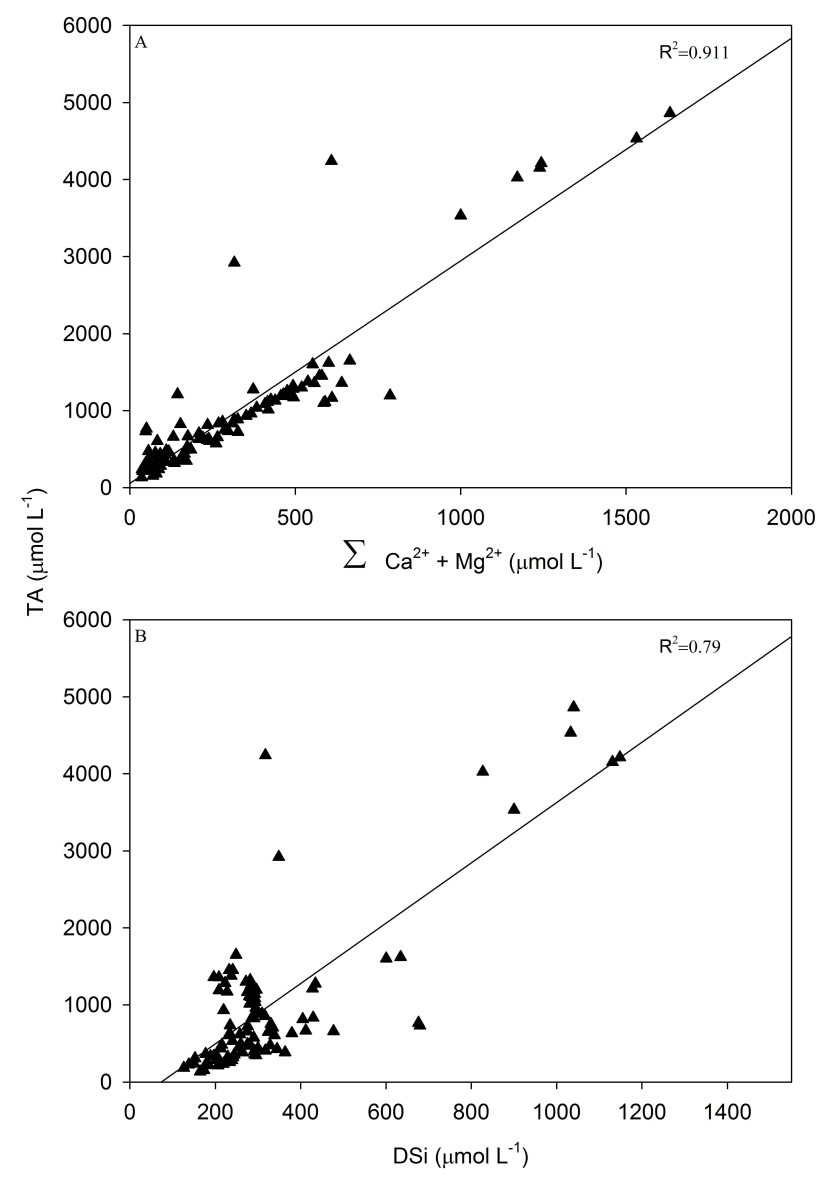

Fig. 14. Total alkalinity against (A) the sum of $\mathrm{Ca}^{2+}$ and $\mathrm{Mg}^{2+}$ concentrations along the Tana River basin and (B) dissolved silicate along the Tana River basin.

ing $\mathrm{HCO}_{3}^{-}$unaffected. The stoichiometric model of Garrels and Mackenzie (1971) assumes that the weathering of silicate rocks leads to a release of $\mathrm{HCO}_{3}^{-}$and $\mathrm{DSi}$ according to a $1: 2$ ratio. However, the dissolution of certain silicates such as plagioclase feldspar $\left(\mathrm{NaCaAl}_{3} \mathrm{Si}_{5} \mathrm{O}_{16}\right)$ may lead to the release of $\mathrm{HCO}_{3}^{-}$and DSi according to a $6: 4$ ratio. When we apply this ratio to the data points of Nyambene Hills rivers, the recomputed modelled $\mathrm{TA}$ is in better agreement with observed TA than based on the $\mathrm{HCO}_{3}^{-}$: DSi ratio of $1: 2$ (Fig. 15).

The dynamics of riverine $\delta^{13} \mathrm{C}_{\mathrm{DIC}}$ are primarily controlled by both in-stream and watershed processes (Finlay and Kendall, 2007). The wide range of $\delta^{13} \mathrm{C}_{\text {DIC }}$ values recorded in the present study $(-15.0$ to $-2.4 \%$ ) suggests variable carbon sources. The $\delta^{13} \mathrm{C}_{\text {DIC }}$ values of the Aberdare Range $(-6.8 \pm 1.6 \%$ ) and Mt Kenya $(-6.7 \pm 2.4 \%$ ) tributaries, and particularly those in high-altitude regions $(>1700 \mathrm{~m})$, were characterised by high $\delta^{13} \mathrm{C}_{\text {DIC }}$ values consistent with carbonate mineral weathering. These high values may be reinforced by the fact that high-altitude tributaries are characterised by fast and turbulent flows, thus enhancing $\mathrm{CO}_{2}$ 


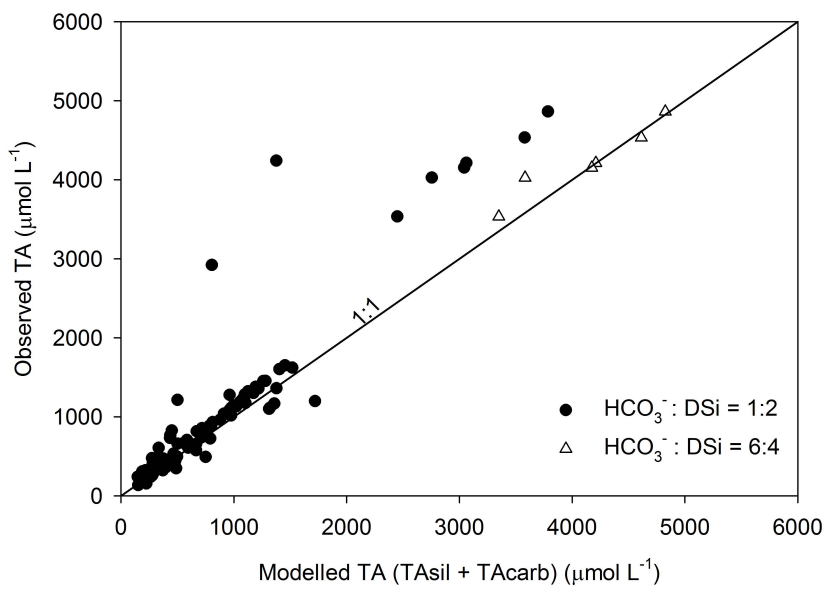

Fig. 15. Observed total alkalinity against modelled total alkalinity along the Tana River basin.

evasion to the atmosphere. Since the $\mathrm{CO}_{2}$ fraction is isotopically depleted relative to $\mathrm{HCO}_{3}^{-}$and $\mathrm{CO}_{3}^{2-}$, this process leads to a gradual enrichment of the remaining DIC pool (e.g. Doctor et al., 2008). We investigated the downstream $(<1 \mathrm{~km})$ gradients from the Satima springs, a highaltitude stream in the Aberdare Range $(3600 \mathrm{~m})$. We noticed a rapid increase in $\delta^{13} \mathrm{C}_{\text {DIC }}$ values $(-20.8$ to $-8.8 \%$ ) over the first $200 \mathrm{~m}$, corresponding to a fast decrease in $p \mathrm{CO}_{2}$ (4789 to $468 \mathrm{ppm}$ ) due to rapid $\mathrm{CO}_{2}$ degassing into the atmosphere (Fig. 16). High $\delta^{13} \mathrm{C}_{\text {DIC }}$ values $(-4.5 \pm 0.1 \%, n=4)$ were recorded at Masinga Reservoir during the dry season campaign (Bouillon et al., 2009), consistent with $\mathrm{CO}_{2}$ degassing combined with $\mathrm{CO}_{2}$ consumption by primary production. The increase in water residence time at the reservoir also favours $\mathrm{CO}_{2}$ exchange with the atmosphere. High primary production was demonstrated by high chlorophyll $a$ concentrations in the Masinga Reservoir. Similar observations have been reported in other dammed rivers (Brunet et al., 2005; Zeng et al., 2011). $\delta^{13} \mathrm{C}_{\mathrm{DIC}}$ values were relatively depleted in the lower Tana mainstream during the three seasons. Lower $\delta^{13} \mathrm{C}_{\text {DIC }}$ values correlated with an increase in total suspended matter (TSM) (Bouillon et al., 2009; Tamooh et al., 2012), suggesting that degradation of laterally derived organic matter plays an important role in controlling $\delta^{13} \mathrm{C}_{\text {DIC }}$ values along the lower Tana River mainstream. When excluding values from Nyambene Hills tributaries, the negative relationship between $\delta^{13} \mathrm{C}_{\text {DIC }}$ values and DIC concentration (Pearson correlation: $p<0.01, r^{2}=0.62 ; n=39$ ) and the positive correlation between $\delta^{13} \mathrm{C}_{\mathrm{DIC}}$ values and DO (Pearson correlation: $p<0.01, r^{2}=0.52 ; n=39$ ) during the wet season campaign further suggests the contribution of organic matter degradation.

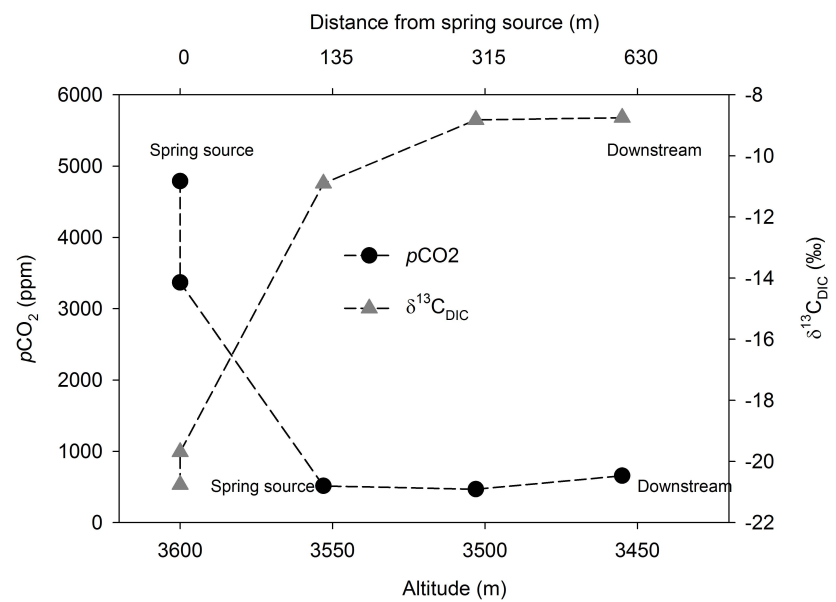

Fig. 16. A plot showing behaviour of $\mathrm{CO}_{2}$ concentration and $\delta^{13} \mathrm{C}_{\text {DIC }}$ at the Satima springs groundwater source in the headwaters of the Aberdare Range.

\subsection{Factors regulating $p \mathrm{CO}_{2}$ and $\mathrm{CO}_{2}$ fluxes}

As reported for other tropical rivers (Richey et al., 2002; Mayorga et al., 2005; Aufdenkampe et al., 2011), the Tana River was generally supersaturated in $\mathrm{CO}_{2}$ with respect to atmospheric equilibrium. This was the case during all three seasons. The overall median $p \mathrm{CO}_{2}$ for the Tana River $(1002 \mathrm{ppm})$ is, however, relatively low compared to the global median of $\sim 3600$ and $\sim 4300 \mathrm{ppm}$ for tropical rivers and streams, respectively (Aufdenkampe et al., 2011). The Tana River tributaries at high altitudes were characterised by relatively low $p \mathrm{CO}_{2}$ concentrations compared to other tropical high-altitude streams, e.g. 11000 to $25000 \mathrm{ppm}$ for Amazon headwaters (Davidson et al., 2010). One possible explanation is relatively low in-stream respiration as Tana River headwater streams are characterised by low suspended sediment (Bouillon et al., 2009; Tamooh et al., 2012) and low temperatures, resulting in lower $\mathrm{CO}_{2}$ production from organic matter degradation. In addition, the $\mathrm{CO}_{2}$ carried by groundwater inputs rapidly degasses to the atmosphere, as observed in the Aberdare Range headwaters. The $\mathrm{CO}_{2}$ from groundwater at Satima springs rapidly degassed (4789 to $468 \mathrm{ppm}$ ) with increasing distance from the spring source (Fig. 16), resulting in $\sim 90 \% \mathrm{CO}_{2}$ evasion over a distance of a few hundred metres. Similar observations have been reported from both temperate (Doctor et al., 2008; Wallin et al., 2012) and tropical headwater streams (Johnson et al., 2008; Davidson et al., 2010), thus depicting small streams as hotspots for $\mathrm{CO}_{2}$ evasion. Further, we observed a strong coupling between isotopic signatures of DIC and $p \mathrm{CO}_{2}$ where ${ }^{13} \mathrm{C}_{\text {DIC }}$ values ( -20.8 to $-8.8 \%$ o ) became rapidly enriched downstream, thus providing further evidence of rapid degassing downstream from groundwater inputs (Fig. 16). In contrast to Aberdare and Mt Kenya streams, Nyambene Hills tributaries recorded relatively high $p \mathrm{CO}_{2}$ values (median 
1377 ppm, $n=12$; Fig. $6 \mathrm{~b}$ ) as well as high $\mathrm{CO}_{2}$ evasion (median $\sim 260 \mathrm{mmol} \mathrm{m}^{-2} \mathrm{~d}^{-1}$, Fig. 7, Supplement Table 1), notably in Murera and Mutundu tributaries during both the wet and end of wet season campaigns. However, Nyambene Hills tributaries were characterised by a cover of high organic matter on the river bed up to $17 \%$ (Tamooh et al., 2012), possibly contributing to additional generation of $\mathrm{CO}_{2}$ through respiration. This way, Nyambene Hills subcatchment emerges as a major hotspot for $\mathrm{CO}_{2}$ emissions within the Tana River basin.

Primary production strongly controlled $p \mathrm{CO}_{2}$ in the reservoirs, as demonstrated by low $p \mathrm{CO}_{2}$ values during the dry season at Masinga Reservoir (313 to 443 ppm) and Kamburu Dam during both the wet (118 ppm) and end of the wet season (305 ppm) campaigns (Supplement Table 1). Low turbidity coupled with high water residence time and temperatures $\left(\sim 30^{\circ} \mathrm{C}\right)$ in the reservoirs enhanced phytoplankton production, thus consuming $\mathrm{CO}_{2}$. In contrast, the depth profile data obtained at Masinga Dam (up to $15 \mathrm{~m}$ deep) recorded consistently high $p \mathrm{CO}_{2}$ values ( $3385 \pm 212 \mathrm{ppm}, n=5$ ) during the end of the wet season campaign. This suggests that the dam water was vertically mixed owing to the fact that this sampling campaign coincided with an unusual dam infilling (following high precipitation in headwaters) and excess outflow at the spillway, thus enhancing upwelling. Furthermore, a maximal $p \mathrm{CO}_{2}$ value $(5059 \mathrm{ppm}$ ) was recorded at $20 \mathrm{~m}$ depth (Supplement Table 1). Conversely, Kamburu Dam recorded highly stratified $p \mathrm{CO}_{2}$ values during both the wet season (118 ppm at surface waters and $2556 \mathrm{ppm}$ at $20 \mathrm{~m}$ depth) and end of the wet season campaigns ( $305 \mathrm{ppm}$ at surface waters and $3270 \mathrm{ppm}$ at $20 \mathrm{~m}$ depth) (Supplement Table 1). In addition, consistently high $p \mathrm{CO}_{2}$ values (up to $5204 \mathrm{ppm}$ ) and $\mathrm{CO}_{2}$ flux $\left(600 \mathrm{mmol} \mathrm{m}^{-2} \mathrm{~d}^{-1}\right)$ were recorded downstream of the Masinga Reservoir exit (Masinga Bridge), a phenomenon we attribute to the release of hypolimnetic, $\mathrm{CO}_{2}$-rich water. However, the $\mathrm{CO}_{2}$ degassed rapidly $<5 \mathrm{~km}$ downstream, where we observe $\sim 90 \%$ of $\mathrm{CO}_{2}$ being degassed before reaching the entrance of Kamburu Dam (Supplement Table 1). Thus, Masinga Reservoir contributes significantly to $\mathrm{CO}_{2}$ emission downstream, consistent with observations reported in some tropical reservoirs where $\mathrm{CO}_{2}$ fluxes ranging from 412 to $1494 \mathrm{mmol} \mathrm{m}^{-2} \mathrm{~d}^{-1}$ were recorded immediately downstream of the reservoirs (Guérin et al., 2006; Abril et al., 2005).

While different in-stream and watershed processes regulate riverine $p \mathrm{CO}_{2}$ dynamics, organic matter respiration within the river seemed to be the major controlling process in the Tana River mainstream, as reflected by high $p \mathrm{CO}_{2}$ values during the 2009 wet season campaign. Furthermore, the lower Tana River mainstream was characterised by high suspended sediment and dissolved organic carbon, thus fuelling in-stream respiration (Tamooh et al., 2012). This is further corroborated by the general negative correlation observed between $\delta^{13} \mathrm{C}_{\text {DIC }}$ values and $p \mathrm{CO}_{2}$ values (Fig. 6a). In-stream processing and decomposition of terrestrially derived organic carbon have been reported to primarily regulate $\mathrm{CO}_{2}$ evasion in most large tropical rivers (Richey et al., 2002; Mayorga et al., 2005).

\subsection{Dynamics of aquatic metabolism}

River metabolism is primarily influenced by the availability of light, nutrients, temperature and organic matter subsidies. Both primary production rates and chlorophyll $a$ concentrations increased consistently downstream in the Tana River basin (Fig. 9), contrary to expectation, as the turbidity increased downstream (Bouillon et al., 2009; Tamooh et al., 2012). However, primary production rates here are based on incubations of surface water within the euphotic zone $(\sim 0.5 \mathrm{~m}$ deep $)$ and do not represent depth-integrated values (deeper in the water column light is obviously extinct). The downstream increase in primary production can be attributed to higher temperatures coupled with higher water residence time in the lower Tana River mainstream. In addition, during the wet season, the nitrate concentrations increased downstream (Pearson correlation: $r^{2}=0.75, p<0.01 ; n=50$; Fig. 8b), particularly along the lower Tana River mainstream, thus potentially enhancing primary production. This counterintuitive observation of high productivity in turbid rivers has also been reported for some large temperate rivers, such as the Mississippi (Kendall et al., 2001; Delong and Thorp, 2006) and Meuse (Descry and Gosselain, 1994), as well as in the White Nile (Sinada and Karim, 1984). While most headwater tributaries are characterised by low suspended matter, primary production rates were low owing to nutrient limitation, low temperature and high stream flow velocity - factors unfavourable for efficient phytoplankton production. Generally, primary production in tropical rivers has been reported to be quite variable ranging from lows of 10$200 \mathrm{mg} \mathrm{C} \mathrm{m}^{-2} \mathrm{~d}^{-1}$ to over $1000 \mathrm{mg} \mathrm{C} \mathrm{m}^{-2} \mathrm{~d}^{-1}$ in relatively unpolluted systems, but can exceed $6000 \mathrm{mg} \mathrm{m}^{-2} \mathrm{~d}^{-1}$ in polluted systems (Davies et al., 2008).

The mean river depth between Kora Bridge and the Tana River mouth during the wet season ranges between 2.0 and $3.0 \mathrm{~m}$, while the average respiration rate along the same stretch was $1.92 \pm 0.72 \mu \mathrm{mol} \mathrm{O} \mathrm{L}^{-1} \mathrm{~h}^{-1}$. This would translate to a depth-integrated pelagic respiration ranging between 92 and $138 \mathrm{mmol} \mathrm{m}^{-2} \mathrm{~d}^{-1}$, while the median $\mathrm{CO}_{2}$ efflux was $156 \mathrm{mmol} \mathrm{C} \mathrm{m}^{-2} \mathrm{~d}^{-1}$ (Table 2, Fig. 7a). Assuming the net primary production is negligible; this suggests that the bulk of $\mathrm{CO}_{2}$ evasion (77 to $114 \%$ ) along the lower Tana mainstream can be accounted for by in-stream respiration (Table 2, Fig. 7a). These estimates are based on the assumption that the respiration quotient between $\mathrm{O}_{2}$ and $\mathrm{CO}_{2}$ is 1.3, as suggested by Richardson et al. (2013). Similar observations have been reported in the Amazon Basin, where instream respiration was highly variable but could account for up to $\sim 100 \%$ of the $\mathrm{CO}_{2}$ evasion in some rivers (Ellis et al., 2012).

In contrast, most headwater tributaries in the Tana River basin are shallow $(\sim 0.5-1 \mathrm{~m} \quad$ deep $)$, with 
Table 1. Summary of the ranges in physico-chemical parameters for diurnal sampling sites.

\begin{tabular}{llrrrrr}
\hline Site & $\begin{array}{l}\text { Sampling } \\
\text { date }\end{array}$ & $\begin{array}{r}\text { Mean depth } \\
(\mathrm{m})\end{array}$ & $\begin{array}{r}\text { DO } \\
(\%)\end{array}$ & $\mathrm{pH}$ & $\begin{array}{r}T \\
\left({ }^{\circ} \mathrm{C}\right)\end{array}$ & $\begin{array}{r}\text { SC } \\
\left(\mu \mathrm{S} \mathrm{cm}^{-1}\right)\end{array}$ \\
\hline Chania Stream & $12 / 09 / 2009$ & 0.5 & $98.4-124.0$ & $7.67-8.25$ & $6.9-16.6$ & $50-53$ \\
Masinga Dam & $27 / 06 / 2010$ & 20 & $63.0-73.6$ & $6.98-7.12$ & $22.0-23.4$ & $71-75$ \\
Tana mainstream & $20 / 07 / 2010$ & 3 & $96.7-99.9$ & $7.83-7.88$ & $24.6-25.8$ & $134-137$ \\
\hline
\end{tabular}

Range for each parameter $-\mathrm{DO}=$ dissolved oxygen saturation; $T=$ temperature; $\mathrm{SC}=$ specific conductivity

Table 2. Comparison between $\mathrm{CO}_{2}$ flux evasion and depth-integrated $R$ during the 2009 wet season campaign.

\begin{tabular}{lrrrr}
\hline Site & $\begin{array}{r}\text { Mean river } \\
\text { depth }(\mathrm{m})\end{array}$ & $\begin{array}{r}\text { Median } \mathrm{CO}_{2} \text { flux } \\
\left(\mathrm{mmol} \mathrm{C} \mathrm{m}^{-2} \mathrm{~d}^{-1}\right)\end{array}$ & $\begin{array}{r}\text { Depth-integrated } R \\
\left(\mathrm{mmol} \mathrm{C} \mathrm{m}^{-2} \mathrm{~d}^{-1}\right)\end{array}$ & $\begin{array}{r}\text { \% of } \mathrm{CO}_{2} \text { evasion } \\
\text { accounted for by } R\end{array}$ \\
\hline Aberdares streams & $\sim 0.5-1.0$ & 38 & $13-26$ & $34-68$ \\
Mt Kenya streams & $\sim 0.5-1.0$ & 85 & $21-43$ & $25-51$ \\
Nyambene Hills streams & $\sim 0.5-1.0$ & 260 & $14-27$ & $5-10$ \\
Tana River mainstream & $\sim 2.0-3.0$ & 156 & $120-179$ & $77-114$ \\
\hline
\end{tabular}

depth-integrated respiration rates ranging between $\sim 10$ and $33 \mathrm{mmol} \mathrm{m} \mathrm{m}^{-2} \mathrm{~d}^{-1}$, while the median $\mathrm{CO}_{2}$ fluxes ranged between 38 and $260 \mathrm{mmol} \mathrm{m}^{-2} \mathrm{~d}^{-1}$ (Table 2, Fig. 7a). This implies that in-stream respiration accounts for a smaller fraction of total $\mathrm{CO}_{2}$ evasion (5 to $68 \%$ ) in the studied tributaries compared to the Tana River mainstream. This is particularly the case for the Nyambene Hills tributaries, whose pelagic respiration accounts for only 5 to $10 \%$ of total $\mathrm{CO}_{2}$ evasion (Table 2, Fig. 7a). This suggests the excess bulk $\mathrm{CO}_{2}$ evasion must be sustained by other processes such as inputs of groundwater (highly $\mathrm{CO}_{2}$ oversaturated to soil and root respiration) and/or in-stream benthic respiration. The latter hypothesis is in agreement with the fact that most Nyambene Hills tributaries were characterised by high organic matter on the bottom of the river bed possibly fuelling respiration.

\subsection{Factors regulating diurnal variations in surface water biogeochemistry}

Diurnal fluctuations of biogeochemical variables were substantial in the Chania headwater stream, moderate at Masinga Reservoir and not detectable within the lower Tana mainstream. Dissolved oxygen was supersaturated with respect to atmospheric equilibrium at the headwaters site (Chania Stream), reaching a maximum value of $124.0 \%$ during daytime (11:00) and minimum saturation of $89.4 \%$ at 06:00, shortly before sunrise. Similarly, the $\mathrm{pH}$ increased during daytime (indicative of $\mathrm{CO}_{2}$ consumption by photosynthesis) and decreased at night (indicative of $\mathrm{CO}_{2}$ release by respiration). These patterns were absent at both the Masinga Dam and lower Tana River mainstream, where biogeochemical parameters remained nearly constant during the whole diurnal cycle. Masinga Dam surface waters were particularly undersaturated in DO (63.0 to $73.6 \%$, Table 1), suggesting the dominance of respiration and net heterotrophy. The absence and/or small fluctuation of DO at Masinga and the Tana River mainstream may be attributed to high suspended loads (Bouillon et al., 2009; Tamooh et al., 2012), which attenuate photosynthetic light, as opposed to the headwaters site (Chania Stream), which is characterized by low suspended matter concentrations.

The $\delta^{18} \mathrm{O}_{\text {DO }}$ signatures fluctuated by $\sim 3.0,2.8$, and $0.9 \%$ o at Chania Stream headwaters, Masinga Reservoir and Tana River mainstream, respectively. The signatures at Chania Stream were isotopically light during daytime and enriched at night, fluctuating slightly below and above the atmospheric equilibrium value $(+24.2 \%$ ). This suggests that aquatic $P$ dominated riverine biological activities during the day but reversed to $R$ dominance at night. Similar observations have been reported in small streams elsewhere (Parker et al., 2005; Waldron et al., 2007; Gammons et al., 2011; Parker et al., 2010; Nimick et al., 2011). In contrast, Masinga Dam and Tana River mainstream $\delta^{18} \mathrm{O}_{\mathrm{DO}}$ signatures were consistently above atmospheric equilibrium $(+24.2 \%)$, suggesting the two sites were dominated by $R$ and thus predominantly heterotrophic during the whole diurnal period.

Precipitation and dissolution of $\mathrm{CaCO}_{3}$ in freshwaters can be deduced from changes in TA (e.g. McConnaughey et al., 1994). At Masinga Dam and Tana River mainstream, TA did not show a distinct pattern during the diurnal cycle. For Chania Stream, the TA values followed a regular pattern, with a decrease from 01:00 to 13:00 of about $0.035 \mathrm{mmol} \mathrm{L}^{-1}$, (Fig. 13b) inconsistent with the one expected from daily cycles of precipitation/dissolution of $\mathrm{CaCO}_{3}$ (increase of TA during night-time and decrease of TA during daytime; de Montety et al., 2011; Gammons et al., 2011). The changes of TA at Chania Stream followed those of conductivity, suggesting overall changes in the chemistry of flowing waters rather 
than in-stream processes affecting TA. We conclude that changes in DIC can be ascribed to $P$ and $R$ and that precipitation/dissolution of $\mathrm{CaCO}_{3}$ was not a major process contributing to daily changes of DIC. The DIC concentration showed a fluctuation of $\sim 0.067,0.116$, and $0.072 \mathrm{mmol} \mathrm{L}^{-1}$ at Chania Stream, Masinga Reservoir and Tana River mainstream, respectively. However, DIC concentrations and $\delta^{13} \mathrm{C}_{\text {DIC }}$ values showed a strong inverse relationship (Pearson correlation: $p<0.01, r^{2}=0.87 ; n=22$; Fig. $11 \mathrm{c}$ ) characterised by a pronounced diurnal cycle at Chania Stream only. DIC concentrations at Chania Stream increased at night due to aquatic community respiration, and decreased during daytime due to $\mathrm{CO}_{2}$ uptake by photosynthesis. Studies elsewhere have reported substantial diurnal changes in DIC concentrations ranging from 0.300 to $0.420 \mathrm{mmol} \mathrm{L}^{-1}$ (Poulson and Sullivan, 2010; Gammons et al., 2011) with a record fluctuation of $\sim 1.133 \mathrm{mmol} \mathrm{L}^{-1}$ reported by Parker et al. (2010). However, this large diurnal change in DIC concentration is reported to have been driven by unique calcite precipitation and not in-stream $P$ or $R$ (Gammons et al., 2007; Nimick et al., 2011).

Similarly, $\delta^{13} \mathrm{C}_{\text {DIC }}$ values at Chania Stream showed a modest fluctuation of $\sim 1.4 \%$, with signatures increasing during daytime as ${ }^{12} \mathrm{CO}_{2}$ was preferentially utilised by aquatic periphyton phototrophs at a faster rate than ${ }^{13} \mathrm{CO}_{2}$. At night, $\delta^{13} \mathrm{C}_{\mathrm{DIC}}$ signatures were isotopically depleted as $\mathrm{CO}_{2}$ was released as a result of aquatic community respiration. In contrast, $\delta^{13} \mathrm{C}_{\mathrm{DIC}}$ at Masinga Dam and the Tana River mainstream showed minor fluctuations $(\sim 0.8$ and $0.9 \%$, respectively) and did not exhibit systematic diurnal patterns.

Chania Stream showed strong diurnal cycles for both $p \mathrm{CO}_{2}$ and $\mathrm{CO}_{2}$ fluxes, with in-stream $P$ and $R$ as the major drivers as reflected by a strong negative correlation between DO and $p \mathrm{CO}_{2}$ (Pearson correlation: $p<0.01, r^{2}=$ 0.74; Fig. 11e). In contrast, $p \mathrm{CO}_{2}$ at Masinga Dam (2621 to $3684 \mathrm{ppm}$ ) and Tana River mainstream (980 to $1131 \mathrm{ppm}$ ) was consistently above atmospheric equilibrium ( $385 \mathrm{ppm})$, and the two sites were sources of $\mathrm{CO}_{2}$ to the atmosphere during the whole diurnal period ( 95 to $331 \mathrm{mmol} \mathrm{CO}_{2} \mathrm{~m}^{-2} \mathrm{~d}^{-1}$ at Masinga; 2 to $16 \mathrm{mmol} \mathrm{CO}_{2} \mathrm{~m}^{-2} \mathrm{~d}^{-1}$ in the lower Tana River). While the general observation is that in-stream $P$ and $R$ control biogeochemical processes in Chania Stream, it is worth mentioning that $P$ is largely driven by periphyton as outlined below. We computed net community production (NCP), gross primary production (GPP) and respiration $(R)$ at community level based on the diurnal changes of $\mathrm{O}_{2}$, using an oxygen mass balance, the so-called Odum method (Odum, 1956). Accordingly, the hourly change of $\mathrm{O}_{2}$ in surface waters during night-time corresponds to the hourly rate of community respiration (CR); the hourly change of $\mathrm{O}_{2}$ in surface waters during daytime corresponds to the hourly rate of net community production. Assuming that the hourly rate of community respiration is constant through the daily cycle, the hourly rate of GPP is computed as NCP+CR. In order to account for the effect of changes of tempera- ture on the solubility of $\mathrm{O}_{2}$, we used apparent oxygen utilisation (AOU) night-time temporal changes to compute $R$ during the $24 \mathrm{~h}$ cycle at Chania from the linear regression of AOU versus time. The change of AOU as a function of time was very linear $\left(r^{2}=0.84\right)$ and yielded an $R$ value of $2.44 \pm 0.33 \mu \mathrm{mol} \mathrm{O} \mathrm{L}^{-1} \mathrm{~h}^{-1}$. The change of oxygen during daytime corresponds to the difference between gross primary production (GPP) and $R$. If the rate of $R$ during night-time is considered to be the same as during daytime, then this allows for GPP to be computed. The daytime temporal change of AOU computed by linear regression at Chania allowed for computation of a GPP value of $6.41 \pm 3.92 \mu \mathrm{mol} \mathrm{O}_{2} \mathrm{~L}^{-1} \mathrm{~h}^{-1}$. The error on the GPP estimate is higher than on the $R$ estimate because the AOU data showed more scatter during daytime $\left(r^{2}=0.19\right)$. The oxygen mass balance approach provides estimates of metabolic rates (GPP and $R$ ) at community level, integrating both planktonic and benthic compartments. Both GPP and $R$ based on the oxygen mass balance have rates $\left(6.41\right.$ and $\left.2.44 \mu \mathrm{mol} \mathrm{O} \mathrm{O}^{-1} \mathrm{~h}^{-1}\right)$ that are one to three orders of magnitude higher than those derived from planktonic incubations $\left(0.006\right.$ and $\left.0.40 \mu \mathrm{mol} \mathrm{O}_{2} \mathrm{~L}^{-1} \mathrm{~h}^{-1}\right)$. This can be due to the strong contribution to community metabolism of periphyton and benthic bacterial respiration.

The $\mathrm{CO}_{2}$ flux measurements with floating domes in aquatic environments have been criticised in the past for a variety of possible biases (Raymond and Cole 2001), although there is evidence that these measurements provide reasonable estimates of k600 (Guérin et al., 2007; Vachon et al., 2010). The k600 values we obtained are consistent with those typically reported for streams (Wanninkhof et al., 1990), rivers (Raymond and Cole 2001) and lakes (Cole and Caraco, 1998). The higher k600 values at Chania Stream compared to Tana River fit the pattern described by Raymond et al. (2012) of k600 decreasing with increasing stream order. The higher k600 at Masinga Reservoir compared to the Tana River might be related to lower fetch limitation and more exposure leading to higher contribution of wind-induced turbulence to k600 (Borges and Abril, 2011).

\section{Conclusions}

While the wide range of $\delta^{13} \mathrm{C}_{\text {DIC }}$ values ( -20.8 to $-2.4 \%$ ) in the Tana River basin suggests variable DIC sources, the primary process regulating of DIC concentrations is weathering, as clearly demonstrated by a strong correlation between $\mathrm{TA}$ and the sum of $\mathrm{Ca}^{2+}$ and $\mathrm{Mg}^{2+}$ concentration. However, Nyambene Hills subcatchment is lithologically distinct from the rest of the basin, as reflected by its systematically high TA during all seasons. Global syntheses suggest that streams are generally characterised by higher $p \mathrm{CO}_{2}$ than large rivers, but our data show the opposite pattern with higher concentrations of $\mathrm{CO}_{2}$ recorded at the Tana River mainstream compared to headwater streams. Chlorophyll $a$ and primary production increased consistently downstream, contrary to what could be 
expected from the RCC and from high TSM concentrations, due to favourable conditions for phytoplankton development such as high nutrients, temperature and water residence time. In-stream $R$ in the lower Tana River mainstream accounted for the bulk of total $\mathrm{CO}_{2}$ evasion (77 to $114 \%$ ) to the atmosphere, while it could only account for 5 to $68 \%$ of $\mathrm{CO}_{2}$ evasion in headwaters, thus pointing toward greater contributions by other watershed processes or in-stream processes such as benthic respiration. Focusing on a depth-integrated primary production measurement in future is critical in order to give an accurate estimate of $P: R$ ratios for Tana River. The diurnal biogeochemical fluctuations were substantial in headwater streams, moderate at Masinga Reservoir and not detectable at Tana River mainstream Masinga Reservoir and Tana River mainstream. However, the timing for Masinga Reservoir sampling was unusual due to infilling of the reservoir resulting in high water turbulence associated with high turbidity and vertical mixing of water, thus diurnal biogeochemical fluctuations at Masinga Dam were not representative of a typical situation. Hence, there is a need to focus on a more representative diurnal sampling in the reservoirs in future studies, particularly the during dry season, when phytoplankton production is expected to be significant.

\section{Supplementary material related to this article is available online at http://www.biogeosciences.net/10/ 6911/2013/bg-10-6911-2013-supplement.pdf.}

Acknowledgements. Funding for this work was provided by the Research Foundation Flanders (FWO-Vlaanderen, project G.0651.09 and travel grants to F. Tamooh, K. Van Den Meersche, and S. Bouillon), and the European Research Council (ERC-StG 24002, AFRIVAL - African river basins: catchment-scale carbon fluxes and transformations, http://ees.kuleuven.be/project/afrival/). A. V. Borges is a senior research associate at the FRS-FNRS. We thank Pieter van Rijswijk (NIOZ), Peter van Breugel (NIOZ), Zita Kelemen (KU Leuven) and Marc-Vincent Commarieu (ULg) for technical and laboratory assistance; and the Kenya Wildlife Service for logistical support during sampling. Three anonymous reviewers provided insightful comments and suggestions which greatly improved the manuscript.

Edited by: K. Fennel

\section{References}

Abril, G., Etcheber, H., Delille, B., Frankignoulle, M., and Borges, A. V.: Carbonate dissolution in the turbid and eutrophic Loire estuary, Mar. Ecol.-Prog. Ser., 259, 129-138, 2003.

Abril, G., Guérin, F., Richard, S., Delmas, R., Galy-Lacaux, C., Gosse, P., Tremblay, A., Varfalvy, L., dos Santos, M. A., and Matvienko, B.: Carbon dioxide and methane emissions and the carbon budget of a 10-year old tropical reservoir (Petit
Saut, French Guiana), Global Biogeochem. Cy., 19, GB4007, doi:10.1029/2005GB002457, 2005.

Amiotte-Suchet, P., Aubert, D., Probst, J. L., Gauthier-Lafaye, F., Probst, A., Andreux, F., and Viville. D.: $\delta^{13}$ C pattern of dissolved inorganic carbon in a small granitic catchment: the Strengbach case study (Vosges mountains, France), Chem. Geol., 159, 129145, 1999.

Aufdenkampe, K. A., Mayorga, E., Raymond, A P., Melack, M J., Doney, C. S., Alin, R. S., Aalto, E. R., and Yoo, K.: Riverine coupling of biogeochemical cycles between land, oceans, and atmosphere, Front. Ecol. Environ., 9, 53-60, 2011.

Baker, B. H.: Outline of the petrology of the Kenya rift alkaline province, Geol. Soc. Spec. Publ., 30, 293-311, doi:10.1144/GSL.SP.1987.030.01.14, 1987.

Borges, A. V. and Abril G.: Carbon Dioxide and Methane Dynamics in Estuaries, in: Treatise on Estuarine and Coastal Science Edited by: Wolanski, E. and McLusky, D., Biogeochemistry, Academic Press, Waltham, 5, 119-161, 2011.

Bouillon, S., Abril, G., Borges, A. V., Dehairs, F., Govers, G., Hughes, H. J., Merckx, R., Meysman, F. J. R., Nyunja, J., Osburn, C., and Middelburg, J. J.: Distribution, origin and cycling of carbon in the Tana River (Kenya): a dry season basin-scale survey from headwaters to the delta, Biogeosciences, 6, 2475-2493, doi:10.5194/bg-6-2475-2009, 2009.

Bouwman, A. F., Bierkens, M. F. P., Griffioen, J., Hefting, M. M., Middelburg, J. J., Middelkoop, H., and Slomp, C. P.: Nutrient dynamics, transfer and retention along the aquatic continuum from land to ocean: towards integration of ecological and biogeochemical models, Biogeosciences, 10, 1-22, doi:10.5194/bg10-1-2013, 2013.

Brown, T. and Schneider, H.: From plot to basin: the scale problem in studies of soil erosion and sediment yield, in: The Sustainable Management of Tropical Catchments, edited by: Harper, D. and Brown, T., John Wiley and Sons, Chichester, England, 1998.

Brunet, F., Gaiero, D., Probst, J. L., Depetris, P. J., Gauthier, Lafaye, F., and Stille, P.: $\delta^{13} \mathrm{C}$ tracing of dissolved inorganic carbon sources in Patagonian rivers (Argentina), Hydrol. Process., 19, 3321-44, 2005.

Brunet, F., Dubois, K., Veizer, J., Nkoue Ndondo, G. R., Ndam Ngoupayou, J. R., Boeglin, J. L., and Probst, J. L.: Terrestrial and fluvial carbon fluxes in a tropical watershed: Nyong basin, Cameroon, Chem. Geol., 265, 563-572, 2009.

Bullen, T. D. and Kendall, C.: Tracing of weathering reactions and water flowpaths: a multi-isotope approach, in: Isotope Tracers in Catchment Hydrology, edited by: Kendall, C. and McDonnell, J. J., Elsevier, Amsterdam, 611-646, 1998.

Butman, D. and Raymond, P. A.: Significant efflux of carbon dioxide from streams and rivers in the United States, Nat. Geosci., 4, 839-842, doi:10.1038/ngeo1294, 2011.

Cole, J. J. and Caraco, N. F.: Atmospheric exchange of carbon dioxide in a low-wind oligotrophic lake measured by the addition of SF6, Limnol. Oceanogr., 43, 647-656, 1998.

Cole, J. J. and Caraco, N. F.: Carbon in catchments: connecting terrestrial carbon losses with aquatic metabolism, Mar. Freshwater Res., 52, 101-110, 2001.

Cole, J. J. and Caraco, N. F.: Primary production and its regulation in the tidal-freshwater Hudson River, in: The Hudson River estuary, edited by: Levinton, J. S. and Waldman, J. R., Cambridge University Press, New York, 107-120, 2006. 
Cole, J. J., Prairie, Y. T., Caraco, N. F., McDowell, W. H., Tranvik, L. J., Striegl, R. G., Duarte, C. M., Kortelainen, P., Downing, J. A., Middelburg, J. J., and Melack, J.: Plumbing the global carbon cycle: integrating inland waters into the terrestrial carbon budget, Ecosystems, 10, 171-184, 2007.

Dauchez, S., Legendre, L., and Fortier, L.: Assessment of simultaneous uptake of nitrogenous nutrients $\left({ }^{15} \mathrm{~N}\right)$ and inorganic carbon $\left({ }^{13} \mathrm{C}\right)$ by natural phytoplankton populations, Mar. Biol., 123, 651-666, 1995.

Davidson, E. A., Figueiredo, R. O., Markewitz, D., and Aufdenkampe, A. K.: Dissolved $\mathrm{CO}_{2}$ in small catchment streams of eastern Amazonia: A minor pathway of terrestrial carbon loss, J. Geophys. Res., 115, G04005, doi:10.1029/2009JG001202, 2010.

Davies, P. M., Bunn, E. S., and Hamilton, K. S: primary production in tropical streams and rivers, in: Aquatic ecosystems: tropical stream ecology, edited by: Dudgeon, D., Elsevier Science, London, UK, 23-42, 2008.

Delong, M. D. and Thorp, J. H.: Significance of instream autotrophs in trophic dynamics of the Upper Mississippi River, Oecologia, 147, 76-85, 2006.

de Montety, V., Martin, J. B., Cohen, M. J., Foster, C., and Kurz, M. $\mathrm{J}$. : Influence of diel biogeochemical cycles on carbonate equilibrium in a karst river, Chem. Geol., 283, 31-43, 2011.

Descy, J.-P. and Gosselain, V.: Development and ecological importance of phytoplankton in a large lowland river (River Meuse, Belgium), Hydrobiologia, 289, 139-155, 1994.

Dijkshoorn, J. A., Macharia, P. N., Huting, J. R. M., Maingi, P. M., and Njoroge, C. R. K.: Soil and terrain conditions for the Upper Tana River catchment, Kenya, Green Water Credits Report 11/ISRIC Report 2010/09, ISRIC - World Soil Information, Wageningen, available at: http://www.isric.org/isric/webdocs/Docs/ ISRIC_Report_2010_09.pdf, 2010.

Doctor, D. H., Kendall, C., Sebestyen, S. D., Shanley, J. B., Ohte, N., and Boyer, E. W.: Carbon isotope fractionation of dissolved inorganic carbon (DIC) due to outgassing of carbon dioxide from a headwater stream, Hydrol. Process., 22, 2410-2423, 2008.

Dunne, T. and Ongweny, G. S. O.: A new estimate of sedimentation rates on the upper Tana River, The Kenyan Geographer, 2, 109126, 1976.

Ellis, E. E., Richey, J. E., Aufdenkampe, A. K., Krusche, A. V., Quay, P. D., Salimon, C., and Cunha, H. B.: Factors controlling water-column respiration in rivers of the central and southwestern Amazon Basin, Limnol Oceanogr., 57, 527-540, 2012.

Finlay, J. C.: Controls of streamwater dissolved inorganic carbon dynamics in a forested watershed, Biogeochemistry, 62, 231252, 2003

Finlay, J. C. and Kendall, C.: Stable isotope tracing of temporal and spatial variability in organic matter sources to freshwater ecosystems, in: Stable isotopes in ecology and environmental science, 2nd Edn., edited by: Michener, R. H. and Lajtha, K., Blackwell Publishing, Malden, USA, 283-333, 2007.

Gammons, C. H., Grant, T. M., Nimick, D. A., Parker, S. R., and DeGrandpre, M. D.: Diel changes in water chemistry in an arsenicrich stream and treatment-pond system, Sci. Total Environ., 384, 433-451, 2007.

Gammons, C. H., Babcock, J., Parker, S. R., and Poulson, S. R.: Diel cycling and stable isotopes of dissolved oxygen, dissolved inorganic carbon, and nitrogenous species in a hypereutrophic stream, Chem. Geol., 283, 44-55, 2011.
Garrels R. M. and Mackenzie, F. T.: Evolution of Sedimentary Rocks, W. W. Norton, New York, 397 pp., 1971.

Gazeau, F., Middelburg, J. J., Loijens, M., Vanderborght, J. P., Pizay, M. D., and Gattuso, J. P.: Planktonic primary production in estuaries: comparison of ${ }^{14} \mathrm{C}, \mathrm{O}_{2}$ and ${ }^{18} \mathrm{O}$ methods, Aquat. Microb. Ecol., 46, 95-106, 2007.

Gillikin, D. P. and Bouillon, S.: Determination of $\delta^{18} \mathrm{O}$ of water and $\delta^{13} \mathrm{C}$ of dissolved inorganic carbon using a simple modification of an elemental analyzer - isotope ratio mass spectrometer (EA-IRMS): an evaluation, Rapid Commun. Mass Sp., 21, 14751478, 2007.

GOK-TARDA.: Tana Delta Irrigation Project-Feasibility Study. Vol. III-Hydrology, River Morphology and Flood plain hydraulics, Haskoning-Royal Dutch Consulting Engineers and Architects, Netherlands and Mwenge International Associates Ltd, Nairobi, Kenya, 1982.

Guérin, F., Abril, G., Richard, S., Burban, B., Reynouard, C., Seyler, P., and Delmas, R.: Methane and carbon dioxide emissions from tropical reservoirs: Significance of downstream rivers, Geophys. Res. Lett., 33, L21407, doi:10.1029/2006GL027929, 2006.

Guérin F., Abril G., Serça D., Delon C., Richard S., Delmas R., Tremblay A., and Varfalvy L. Gas transfer velocities of $\mathrm{CO}_{2}$ and $\mathrm{CH}_{4}$ in a tropical reservoir and its river downstream, J. Mar. Syst., 66, 161-172, 2007.

Hughes, H. J., Bouillon, S., André, L., and Cardinal, D.: The effects of weathering variability and anthropogenic pressures upon silicon cycling in an intertropical watershed (Tana River, Kenya), Chem. Geol., 308-309, 18-26, 2012.

Johnson, M. S., Lehmann, J., Riha, S. J., Krusche, A.V., Richey, J. E., Ometto, J. P. H. B., and Couto, E. G.: $\mathrm{CO}_{2}$ efflux from Amazonian headwater streams represents a significant fate for deep soil respiration, Geophys. Res. Lett., 35, L17401, doi:10.1029/2008GL034619, 2008.

Kempe, S.: Sinks of anthropogenically enhanced carbon cycle in surface fresh waters, J. Geophys. Res., 89, 4657-4676, 1984.

Kendall, C., Silva, S. R., and Kelly, V. J.: Carbon and nitrogen isotopic compositions of particulate organic matter in four large river systems across the United States, Hydrol. Process., 15, 1301-1346, 2001.

Maingi, J. K. and Marsh, S. E.: Quantifying hydrologic impacts following dam construction along the Tana River, Kenya, J. Arid Environ., 50, 53-79, 2002.

Maiolini, B. and Bruno, M. C.: The River Continuum Concept revisited: Lessons from the Alps, alpine space - man and environment, 3, 67-76, ISBN 978-3-902571-33-5, 2007.

Mayorga, E., Aufdenkampe, A. K., Masiello, C. A., Krusche, A. V., Hedges, J. I., Quay, P. D., Richey, J. E., and Brown, T. A.: Young organic matter as a source of carbon dioxide outgassing from Amazonian Rivers, Nature, 436, 538-541, 2005.

McConnaughey, T. A., LaBaugh, J. W., Rosenberry, D. O., Striegl, R. G., Reddy, M. M., Schuster, P. F., and Carter, V.: Carbon budget for a groundwater-fed lake: Calcification supports summer photosynthesis, Limnol. Oceanogr., 39, 1319-1332, 1994.

Meybeck, M.: Global chemical-weathering of surficial rocks estimated from river dissolved loads, Am. J. Sci., 287, 401-428, 1987.

Millero, F. J.: The thermodynamics of the carbonate system in seawater, Geochim. Cosmochim. Ac., 43, 1651-1661, 1979. 
Milliman, D. J. and L. K. Farnsworth.: River Discharge to the Coastal Ocean: A Global Synthesis, Cambridge University Press, 2011.

Nimick, D. A., Gammons, C. H., and Parker, S. R.: Diel biogeochemical processes and their effect on the aqueous chemistry of streams: A review, Chem. Geol., 283, 3-17, 2011.

Odum, H. T.: Primary production in flowing waters, Limnol. Oceanogr., 1, 102-117, 1956.

Parker, S. R., Poulson, S. R., Gammons, C. H., and Degrandpre, M. D.: Biogeochemical controls on diel cycling of stable isotopes of dissolved $\mathrm{O}_{2}$ and dissolved inorganic carbon in the Big Hole River, Montana, Environ. Sci. Technol., 39, 7134-7140, doi:10.1021/es0505595, 2005.

Parker, S. R., Gammons, C. H., Poulson, S. R., DeGrandpre, M. D., Weyer, C. L., Smith, M. G., Babcock, J. N., and Oba, Y.: Diel behavior of stable isotopes of dissolved oxygen and dissolved inorganic carbon in rivers over a range of trophic conditions, and in a mesocosm experiment, Chem. Geol., 269, 21-31, 2010.

Poulson, S. R. and Sullivan, A. B.: Assessment of diel chemical and isotopic techniques to investigate biogeochemical cycles in the upper Klamath River, Oregon, USA, Chem. Geol., 269, 3-11, 2010.

Raymond, P. A. and Cole, J. J.: Gas exchange in rivers and estuaries: choosing a gas transfer velocity, Estuaries 24, 312-317, 2001.

Raymond, P. A., Zappa, C. J., Butman, D., Bott, T. L., Potter, J., Mulholland, P., Laursen, A. E., McDowell, W. H., and Newbold, D.: Scaling the gas transfer velocity and hydraulic geometry in streams and small rivers, Limnol. Oceanogr., 2, 41-53, doi:10.1215/21573689-1597669, 2012.

Regnier, P., Friedlingstein, P., Ciais, P., Mackenzie, F. T., Gruber, N., Janssens, I., Laruelle, G. G., Lauerwald, R., Luyssaert, S., Andersson, A.J., Arndt, S., Arnosti, C., Borges, A. V., Dale, A.W., Gallego-Sala, A., Goddéris, Y., Hartmann, J., Heinze, C., Ilyina, T., Joos, F., LaRowe, D. E., Leifeld, J., Meysman, F. J. R., Munhoven, G., Raymond, P. A., Spahni, R., Suntharalingam, P., and Thullner M.: Anthropogenic perturbation of the carbon fluxes from land to ocean, Nat. Geosci., 6, 597-607, 2013.

Richardson, D. C., Newbold, J. D., Aufdenkampe, A. K., Taylor, P. G., and Kaplan, L. A.: Measuring heterotrophic respiration rates of suspended particulate organic carbon from stream ecosystems, Limnol. Oceanogr.-Meth., 11, 247-261, 2013.

Richey, J. E., Melack, J. M., Aufdenkampe, A. K, Ballester, V. M., and Hess, L.: Outgassing from Amazonian rivers and wetlands as a large tropical source of atmospheric $\mathrm{CO}_{2}$, Nature, 416, 617-20, 2002.

Rosatelli, G., Wall, F., and Le Bas, M. J.: Potassic glass and calcite carbonatite in lapilli from extrusive carbonatites at Rangwa Caldera Complex, Kenya, Mineral Mag., 67, 931-955, 2003.
Sebag, D., Verrecchia, E. P., Lee, S. J., and Durand, A.: The natural hydrous sodium silicates from the northern bank of Lake Chad: occurrence, petrology and genesis, Sediment. Geol., 139, 15-31, 2001.

Sinada, F. and Karim, A. G. A.: Primary production and respiration of the phytoplankton in the Blue and White Niles at Khartoum, Hydrobiologia, 110, 57-59, 1984.

Staehr, P. A., Bade, D., Van de Bogert, M. C., Koch, G. R., Williamson, C., Hanson, P., Cole, J. J., and Kratz, T.: Lake metabolism and the diel oxygen technique: State of the science, Limnol. Oceanogr.-Meth., 8, 628-644, 2010.

Tamooh, F., Van den Meersche, K., Meysman, F., Marwick, T. R., Borges, A. V., Merckx, R., Dehairs, F., Schmidt, S., Nyunja, J., and Bouillon, S.: Distribution and origin of suspended matter and organic carbon pools in the Tana River Basin, Kenya, Biogeosciences, 9, 2905-2920, doi:10.5194/bg-9-2905-2012, 2012.

Telmer, K. and Veizer, J.: Carbon fluxes, $p \mathrm{CO}_{2}$ and substrate weathering in a large northern river basin, Canada: carbon isotope perspectives, Chem. Geol., 159, 61-86, 1999.

Vachon, D., Prairie, Y. T., and Cole, J. J.: The relationship between near-surface turbulence and gas transfer velocity in freshwater systems and its implications for floating chamber measurements of gas exchange, Limnol. Oceanogr., 55, 1723-1732, 2010.

Vannote, R. L., Minshall, G. W., Cummins, K. W., Sedell, J. R., and Cushing, C. E.: The river continuum concept, Can. J. Fish. Aquat. Sci., 37, 130-137, 1980.

Venkiteswaran, J. J., Wassenaar, L. I., and Schiff, S. L.: Dynamics of dissolved oxygen isotopic ratios: a transient model to quantify primary production, community respiration, and air-water exchange in aquatic ecosystems, Oecologia, 153, 385-398, 2007.

Waldron, S., E. M. Scott., and Soulsby, C.: Stable isotope analysis reveals lower-order river dissolved inorganic carbon pools are highly dynamic, Environ. Sci. Technol., 41, 6156-6162. 2007.

Wallin, M. B., Grabs, T., Buffam, I., Laudon, H., A., Mats, G. O., and Bishop, K.: Evasion of $\mathrm{CO}_{2}$ from streams - The dominant component of the carbon export through the aquatic conduit in a boreal landscape, Glob. Change Biol., doi:10.1111/gcb.12083, 2012.

Wanninkhof, R., Mulholland, P. J., and Elwood, J. W.: Gas exchange rates for a first-order stream determined with deliberate and natural tracers, Water Resour. Res., 26, 1621-1630, 1990.

Warden, A. J. and Horkel, A: The Geological Evolution of the NE-Branch of the Mozambique Belt (Kenya, Somalia, Ethiopia), Aust. J. Earth Sci., 77, 161-184, 1984.

Woolley, A. R.: Alkaline Rocks and Carbonatites of the World: Part 3: Africa, Geological Society, 384 pp., 2001.

Zeng, F.-W., Masiello, C. A., and Hockaday, W. C.: Controls on the origin and cycling of riverine dissolved inorganic carbon in the Brazos River, Texas, Biogeochemistry, 104, 275-291, doi:10.1007/s10533-010-9501-y, 2011. 